\title{
Efficient perovskite solar cells by combination use of Au nanoparticles and insulating metal oxide
}

Zhang, Chenxi; Luo, Qi; Shi, Jianhua; Yue, Liyang; Wang, Zengbo; Chen, Xiaohong; Huang, Sumei

\section{Nanoscale}

DOI:

10.1039/C6NR09972F

Published: 01/01/2017

Peer reviewed version

Cyswllt i'r cyhoeddiad / Link to publication

Dyfyniad o'r fersiwn a gyhoeddwyd / Citation for published version (APA):

Zhang, C., Luo, Q., Shi, J., Yue, L., Wang, Z., Chen, X., \& Huang, S. (2017). Efficient perovskite solar cells by combination use of Au nanoparticles and insulating metal oxide. Nanoscale, $9(8)$, 2852-2864. https://doi.org/10.1039/C6NR09972F

\footnotetext{
Hawliau Cyffredinol / General rights

Copyright and moral rights for the publications made accessible in the public portal are retained by the authors and/or other copyright owners and it is a condition of accessing publications that users recognise and abide by the legal requirements associated with these rights.

- Users may download and print one copy of any publication from the public portal for the purpose of private study or research.

- You may not further distribute the material or use it for any profit-making activity or commercial gain

- You may freely distribute the URL identifying the publication in the public portal ?
}

Take down policy

If you believe that this document breaches copyright please contact us providing details, and we will remove access to the work immediately and investigate your claim. 


\title{
Efficient Perovskite Solar Cells by Combination use of Au Nanoparticles and Insulating Metal Oxide
}

Chenxi Zhang ${ }^{1}$, Qi Luo ${ }^{1}$, Jianhua Shi $^{2}$, Liyang Yue ${ }^{3}$, Zengbo Wang ${ }^{3}$, Xiaohong Chen ${ }^{1}$, Sumei Huang ${ }^{*}, 1$

${ }^{1}$ Engineering Research Center for Nanophotonics \& Advanced Instrument, Ministry of Education, School of Physics and Materials Science, East China Normal University, North Zhongshan Rd. 3663, Shanghai 200062, P. R. China

${ }^{2}$ New Energy Technology Center, Shanghai Institute of Microsystem and Information Technology, 865 Chang Ning Road, Shanghai 200050, P. R. China

${ }^{3}$ School of Electronic Engineering, Bangor University, Bangor LL57 1UT, UK.

\begin{abstract}
Simultaneously high open circuit voltage and high short circuit current density is a big challenge for achieving high efficient perovskite solar cells due to the complex excitonic nature of hybrid organic - inorganic semiconductors. Herein, we developed a facile and effective method to process efficient plasmonic PSC devices. The solar cells were prepared by incorporating $\mathrm{Au}$ nanoparticles (NPs) into mesoporous $\mathrm{TiO}_{2}$ films and depositing $\mathrm{MgO}$ passivation film on the Au NP modified mesoporous titania by wet spinning and pyrolysis of the magnesium salt. The obtained PSCs by combinational use of $\mathrm{Au}$ NPs and $\mathrm{MgO}$ demonstrated a high power conversion
\end{abstract}

${ }^{*)}$ Corresponding author, email: smhuang@phy.ecnu.edu.cn 
efficiency of $16.1 \%$ with both high open circuit voltage of $1.09 \mathrm{~V}$ and high short-circuit current density of $21.76 \mathrm{~mA} \mathrm{~cm}^{-2}$. The device achieved $34.2 \%$ improvement of the power conversion efficiency compared with the device based on pure $\mathrm{TiO}_{2}$. Moreover, a significant improvement of the UV stability in the perovsikite solar cell is achieved by combinational use of $\mathrm{Au}$ NPs and insulating $\mathrm{MgO}$. The fundamental optics and physics behind regulation of energy flow in perovskite solar cell and concept of using $\mathrm{Au}$ nanoparticles and $\mathrm{MgO}$ to improve the device performance has been explored. The results indicate that the combinational use of $\mathrm{Au}$ nanparticles and $\mathrm{MgO}$ passivation film is an effective way in designing high performance and stability organic - inorganic perovskite photovoltaic materials.

Keywords: Perovskite solar cells, Au nanoparticles, $\mathrm{MgO}$ passivation layer, plasmon enhancement, near-field 


\section{INTRODUCTION}

Photovoltaics has the potential to be the prime candidates for future energy sources and make a large contribution to solving the problem of climate change. Specially, inorganic-organic hybrid perovskite solar cells (PSCs) have provided a lasting impression on the scientific community because of their rapid progress as high efficient and low cost technology. Starting from the first well-known PSCs exploited the device structure of dye-sensitized solar cells (DSSCs) by replacing dye molecules with perovskite crystals in 2009 , in only seven years power conversion efficiencies (PCEs) above $22 \%$ have already been reported and certified. ${ }^{1-4}$ The latest certified PCE value of $22.1 \%$ is approaching to that of commercial monocrystalline silicon solar cells. ${ }^{4}$ Even though such rapid and unprecedented progress for any photovoltaic (PV) material, for instance, silicon, GaAs, CIGS and CdTe, further improvements for PSCs are expected and required in order to completely surpass the other PV technologies and fully realize their potential as solar cells.

In the past seven years, various perovskite absorber materials have been developed, forming a large family of crystalline materials. The most commonly used for $\mathrm{PV}$ devices have an $\mathrm{ABX}_{3}$ chemical composition containing an organic cation A, such as methylammonium $(\mathrm{MA})^{2}$ or formamidinium $(\mathrm{FA})^{5}$, a divalent metal $\mathrm{B}$, such as $\mathrm{Pb}^{2}$ or $\mathrm{Sn},{ }^{6}$ and a halide $\mathrm{X}$, such as $\mathrm{Br}$ or I. These perovskites are processed by a large number of techniques ranging from spin coating, ${ }^{2}$ dip coating, ${ }^{7}$ two-step interdiffusion, ${ }^{8}$ chemical vapour deposition, ${ }^{9}$ thermal evaporation, ${ }^{10}$ solvent 
engineering, ${ }^{11,12}$ to intramolecular exchange processing. ${ }^{13}$ Much of the work in the field of Inorganic-organic hybrid photovoltaics to date has been focused on developing new materials, technological process innovations and device structures to maximize the light absorption, charge separation and collection and voltage output. While we have some basic understanding of the PSC devices as an optical system, there have been limited attempts to exploit the optical designs to manage the light in-coupling and propagation as means to enhance the overall device performance.

One possible method for optical management and achieving fundamental efficiency enhancements in PSC devices is to utilize localized surface plasmon resonance (LSPR) in metallic nanostructures. Surface plasmons (SPs) are electron oscillations excited by either photons or electrons at the metal-dielectric interfaces, associated with well-confined surface electromagnetic waves. ${ }^{14,} 15$ With proper engineering of the metal structures, such confinement can lead to an enhanced electromagnetic field at the metal-dielectric interfaces, which could be utilized for improvement of PV device efficiencies, helping to approach or even surpass the Shockley-Queisser limit without any exotic operating principles. ${ }^{15}, 16$ The use of metal NPs and arrangements of them have been explored for almost all types of solar cells, for example, dye-sensitized, ${ }^{17,18}$ organic, ${ }^{19}$ silicon, ${ }^{20,21}$ and PSC solar cells. ${ }^{22,23}$ As reported by Lee et al., Au NPs were doped in the PEDOT:PSS layer of the P3HT:PCBM device to induce the plasmonic enhancement for the active layer. ${ }^{19}$ The PCE for the device with a low concentration of Au NPs was improved from $3.04 \%$ to 
3.65\%. Slight plasmonic enhancements in the device PV performance were reported in most of the previous studies. In recent studies, nevertheless, Snaith and co-workers demonstrated that the employment of metal oxide $\left(\mathrm{SiO}_{2}, \mathrm{TiO}_{2}\right)$ coated metal $(\mathrm{Au}, \mathrm{Ag})$ NPs into mesoporous $\mathrm{Al}_{2} \mathrm{O}_{3}$ scaffolds induced significant photocurrent enhancements in methylammonium lead iodide based devices. ${ }^{22,23}$ However, these enhancements could not be attributed to increased solar light absorption in the spectral regime of the metal nanoparticle LSPRs. The origin of the enhancement observed in plasmonic PSCs remains unknown. The presence of metal NPs may favor radiative decay of excitons, photon recycling, nonradiative photocarrier generation, light trapping, and help to reduction of the perovskite film thickness and hence decrease of the amount of lead present in the device. ${ }^{15,22-26}$ On the other hand, incorporated metal nanoparticles can act as sites for electron recombination. These factors can competitively have an impact on the performance and the development of the PSC device. Although there have been a few experimental evidences for plasmonic PSCs, many fundamental physical mechanisms are not systematically understood.

In this work, we report a facile and effective method to process efficient plasmonic PSC devices. Our investigation is very different from the previous reports. $\mathrm{Au}$ nanoparticles were incorporated into mesoporous $\mathrm{TiO}_{2}$ films, chiefly on their top surfaces. Then, $\mathrm{MgO}$ passivation films were prepared on the Au NP modified mesoporous titania by wet spinning and pyrolysis of the magnesium salt. Our results showed that combination use of Au NPs and MgO significantly enhanced both the 
current density and the photovoltage of the perovskite solar cells. The energy conversion efficiency of the $\mathrm{Au}$ NPs and $\mathrm{MgO}$ modified perovskite solar cell increased from $12.0 \%$ to $16.1 \%$. The fundamental optics and physics behind the plasmonic perovskite solar cell based on Au nanoparticles and insulating $\mathrm{MgO}$ was studied.

\section{EXPERIMENTAL}

All materials were purchased from either Alfa Aesar or Sigma-Aldrich, unless otherwise stated. $\mathrm{CH}_{3} \mathrm{NH}_{3} \mathrm{I}$ (MAI) was synthesized according to a previous study [12].

$\mathrm{Au}$ nanoparticles were prepared according to the method published previously with slight modification. ${ }^{18}$ A $381 \mu$ portion of hydrogen tetrachloroaurate (III) $\left(\mathrm{HAuCl}_{4} \cdot 3 \mathrm{H}_{2} \mathrm{O}\right)$ aqueous solution $(0.1 \mathrm{M})$ was added into $150 \mathrm{ml} \mathrm{DI}$ water and brought to a rolling boil with stirring, and then $2 \mathrm{ml}$ of $2 \%$ (wt.\%) trisodium citrate dehydrate solution was added. After continuous boiling for about 5 min, the reduction of gold chloride was almost completed. The solution was removed from the heat source and allowed to cool naturally and sit overnight. The obtained solution was used as a seed solution for the Au NPs' preparation. $40 \mu \mathrm{l} \mathrm{HAuCl}_{4} \cdot 3 \mathrm{H}_{2} \mathrm{O}$ solution, $24.9 \mu \mathrm{l}$ hydroquinone and the seed solution were mixed in $50 \mathrm{ml}$ DI water at room temperature under vigorously stirring over $30 \mathrm{~min}$ to obtain colloidal gold solutions with particle size around $40 \mathrm{~nm}$. 
Fluorine-doped tin oxide (FTO) coated slides (Pilkington TEC 15) were patterned by etching with $\mathrm{Zn}$ powders and $2 \mathrm{M} \mathrm{HCl}$. The etched slides were then cleaned with liquid detergent, acetone, ethyl alcohol and de-ionized water for $15 \mathrm{~min}$, respectively, to remove the organic or inorganic residues, and finally dried in a vacuum oven. Isopropyl titanate $(200 \mu \mathrm{l})$ and $5 \mathrm{ml}$ of ethanol were mixed to prepare a clear precursor sol. The precursor sol was spin-coated onto the $\mathrm{Zn} / \mathrm{HCl}$-etched FTO substrate at $4500 \mathrm{rpm}$, followed by annealing at $500{ }^{\circ} \mathrm{C}$ to form a compact $\mathrm{TiO}_{2}$ layer. About $0.4 \mu$ m-thick mesoporous $\mathrm{TiO}_{2}\left(\mathrm{p}-\mathrm{TiO}_{2}\right)$ layer was deposited on the $\mathrm{c}-\mathrm{TiO}_{2}$ by spin-coating $\mathrm{TiO}_{2}$ paste (Dyesol 18NR-T) diluted in anhydrous ethanol (1:3.5, weight ratio) at 2000 r.p.m for $50 \mathrm{~s}$. The layers were then sintered at $500{ }^{\circ} \mathrm{C}$ for 30 minutes in air. After cooling down to the room temperature (RT), the samples were treated using the $\mathrm{TiCl}_{4}$ aqueous solution at $70^{\circ} \mathrm{C}$ for $30 \mathrm{~min}$ and dried at $500{ }^{\circ} \mathrm{C}$ for $30 \mathrm{~min}$. After the mesoporous film sample was cooled down to RT, $80 \mu$ l of Au NPs solution (0.19 $\mathrm{mg} / \mathrm{ml}$ ) was first spin-coated onto the mesoporous film surface, and the samples were heated at $100{ }^{\circ} \mathrm{C}$ for 30 minutes on a hotplate in air. Then, the $\mathrm{MgO}$ precursor solution of $\mathrm{Mg}\left(\mathrm{CH}_{3} \mathrm{COO}\right)_{2}$ in deionized water was spin-coated on the $\mathrm{Au}$ NPs treated $\mathrm{p}-\mathrm{TiO}_{2}$ layer at 3000 r.p.m for $30 \mathrm{~s}$, and then heated at $400{ }^{\circ} \mathrm{C}$ for $1 \mathrm{~h}$ to form $\mathrm{MgO}$ overlayer. The used concentrations of the magnesium salt were $90 \mathrm{mM}$. The perovskite layer was grown by a spin-coating process using a $\gamma$-butyrolactone (GBL) and dimethylsulphoxide (DMSO) solution of $\mathrm{PbI}_{2}$ and $\mathrm{CH}_{3} \mathrm{NH}_{3} \mathrm{I}^{11,}{ }^{12}$ The perovskite precursor solution was prepared by mixing $\mathrm{CH}_{3} \mathrm{NH}_{3} \mathrm{I}(0.1975 \mathrm{~g})$ powders and lead iodide $\mathrm{PbI}_{2}(0.5785 \mathrm{~g})$ in $\operatorname{GBL}(700 \mu \mathrm{l})$ and DMSO $(300 \mu \mathrm{l})$ at $60{ }^{\circ} \mathrm{C}$ for $12 \mathrm{~h}$. The 
formed precursor solution was deposited onto $\mathrm{MgO} / \mathrm{Au} \mathrm{NPs} / \mathrm{p}-\mathrm{TiO}_{2} / \mathrm{c}-\mathrm{TiO}_{2} / \mathrm{FTO}$ sample by a successive two-step spin-coating process, at 2000 r.p.m. for 30 s and at 3500 r.p.m. for 50 s, respectively. Anhydrous chlorobenzene was dripped onto the center of the sample in the second spin-stage during the spin-coating process. The perovskite-precursor coated sample was heated and dried on a hot plate at $120{ }^{\circ} \mathrm{C}$ for $30 \mathrm{~min}$. Notably, at the present concentrations of perovskite solution, a capping layer of solid-perovskite film was formed on top of the mesoporous titanium dioxide. ${ }^{12}$ The hole-transport layer (HTL) was deposited by spin-coating a spiro-OMeTAD solution at 4,000 r.p.m. for $30 \mathrm{~s}$. The spin-coating solution was prepared by dissolving 0.0723 g spiro-MeOTAD, $28.8 \mu \mathrm{l}$ 4-tert-butylpyridine, $17.5 \mu \mathrm{l}$ of a stock solution of $0.520 \mathrm{~g}$ $\mathrm{ml}^{-1}$ lithium bis(trifluoromethylsulphonyl)imide in acetonitrile and $29 \mu \mathrm{l}$ of a stock solution of $0.300 \mathrm{~g} \mathrm{ml}^{-1}$ tris(2-(1H-pyrazol-1-yl)-4-tert-butylpyridine)cobalt(III) bis(trifluoromethylsulphonyl)imide in acetonitrile in $1 \mathrm{ml}$ chlorobenzene. Finally, 100 $\mathrm{nm}$ thick $\mathrm{Ag}$ film with an active area of $0.1 \mathrm{~cm}^{2}$ was evaporated on the Spiro-OMeTAD-coated film. ${ }^{27}$ In order to investigate the possible degradation and enhancement mechanisms in PSC devices by incorporating Au NPs in the active layers, we designed and fabricated four types of PSC devices without Au nanoparticle or $\mathrm{MgO}$ modification, only with $\mathrm{Au} \mathrm{NP}$ modification, only with $\mathrm{MgO}$ coating and with both $\mathrm{Au} \mathrm{NP}$ and $\mathrm{MgO}$ coating. The four kinds of devices were named as S1, S2, S3 and S4, respectively.

The morphology of $\mathrm{Au} \mathrm{NP}$ and $\mathrm{MgO}$ modified $\mathrm{p}-\mathrm{TiO}_{2}$ films was characterized by 
a high-resolution field emission scanning electron microscope (FESEM, Hitachi S4800). Optical spectra of the perovskite films on the differently structured mesoporous $\mathrm{TiO}_{2}$ were examined and characterized by means of ultraviolet-visible light (UV-vis) spectrometer (Hitachi, U-3010). Photoluminescence (PL) spectra were recorded at RT temperature using a HORIBA Jobin Yvon fluoromax-4 fluorescence spectrophotometer with an excitation wavelength of $507 \mathrm{~nm}$. Electrochemical impedance spectroscopy (EIS) measurements of PSCs were recorded with a galvanostat (PG30.FRA2, Autolab, EcoChemie B. V Utrecht, Netherlands). Photocurrent density-voltage $(J-V)$ measurements were performed using an AM 1.5 solar simulator equipped with a 1000 W Xenon lamp (Model No. 91192, Oriel, USA). The solar simulator was calibrated by using a standard Silicon cell (Newport, USA). The light intensity was $100 \mathrm{~mW} \mathrm{~cm} \mathrm{~cm}^{-2}$ on the surface of the test cell. $J-V$ curves were measured using a computer-controlled digital source meter (Keithley 2440) with the reverse direction. During device photovoltaic performance characterization, a metal aperture mask with an opening of about $0.09 \mathrm{~cm}^{2}$ was used. External quantum efficiency (EQE) measurements ( 74125, Oriel, USA) were also carried out for these cells.

\section{RESULTS AND DISCUSSION}

Fig. 1 (a) shows current density versus voltage $(J-V)$ characteristics of the fabricated four types of PSC devices (S1-S4). The corresponding PV parameters including short circuit current density $\left(J_{\mathrm{SC}}\right)$, open circuit voltage $\left(V_{\mathrm{OC}}\right)$, PCE and fill 
factor (FF) are summarized in Table 1. Fig. 1 (b) shows the FESEM image of the top surface morphology the formed p-TiO2 layer containing Au NPs. Fig. 1 (c) shows the FESEM image of the cross-sectional FESEM picture of glass $/ \mathrm{FTO} / \mathrm{c}-\mathrm{TiO}_{2} / \mathrm{Au} \mathrm{Np}$ modified $\mathrm{p}-\mathrm{TiO}_{2}$. From both SEM images, the size of Au NPs (white spheres) is about $40 \mathrm{~nm}$ in diameter, most of Au nanoparticles are distributed on the top surface of the p- $\mathrm{TiO}_{2}$, and the thickness of the porous $\mathrm{TiO} 2$ layer is about $400 \mathrm{~nm}$. The absorbance of the prepared Au NPs in ethanol was shown in Fig. 1 (d). From the figure, the SPR absorbance peak was at $526 \mathrm{~nm}$. Fig. 1 (e) displays an energy diagram of materials for PSC devices with Au NP and MgO modification.

From Table 1, the reference device (S1) without Au NP or MgO coatings exhibits a $V_{\mathrm{OC}}$ of $0.94 \mathrm{~V}, J_{\mathrm{SC}}$ of $19.49 \mathrm{~mA} \mathrm{~cm} \mathrm{~cm}^{-2}$ and $\mathrm{FF}$ of 0.66 , resulting in a total PCE of 12.0\%. After incorporating bare $\mathrm{Au}$ NPs between mesoporous $\mathrm{TiO}_{2}$ and semiconductor perovskite, the device (S2) became poorer and exhibited a PCE of $10.7 \%$. The pure addition of Au NPs significantly decreased both the short-circuit current density and the fill factor. The device (S3) with pure $\mathrm{MgO}$ modification displayed a PCE of $15.1 \%$. Compared with the $\mathrm{TiO}_{2}$-only device (S1), the $V_{\mathrm{OC}}$ value of S3 considerably increased from 0.94 to $1.08 \mathrm{~V}$. The best cell was obtained with both $\mathrm{Au} \mathrm{NP}$ and $\mathrm{MgO}$ coatings. It showed a short-circuit current density of 21.76 $\mathrm{mA} / \mathrm{cm}^{2}$, open-circuit voltage of $1.09 \mathrm{~V}$ and fill factor of 0.68 , yielding the highest efficiency $(\eta)$ of $16.1 \%$. Compared with the $\mathrm{TiO}_{2}$-only device (S1), the power conversion efficiency (PCE) enhancement for the device incorporating Au NPs and 
$\mathrm{MgO}$ mainly comes from the greatly improved short-circuit photocurrent $J_{\mathrm{sc}}$ (19.49 to

$\left.21.76 \mathrm{~mA} / \mathrm{cm}^{2}\right)$ and the open-circuit voltage $V_{\mathrm{OC}}(0.94$ to $1.09 \mathrm{~V})$, whilst the fill factor is only slightly changed.
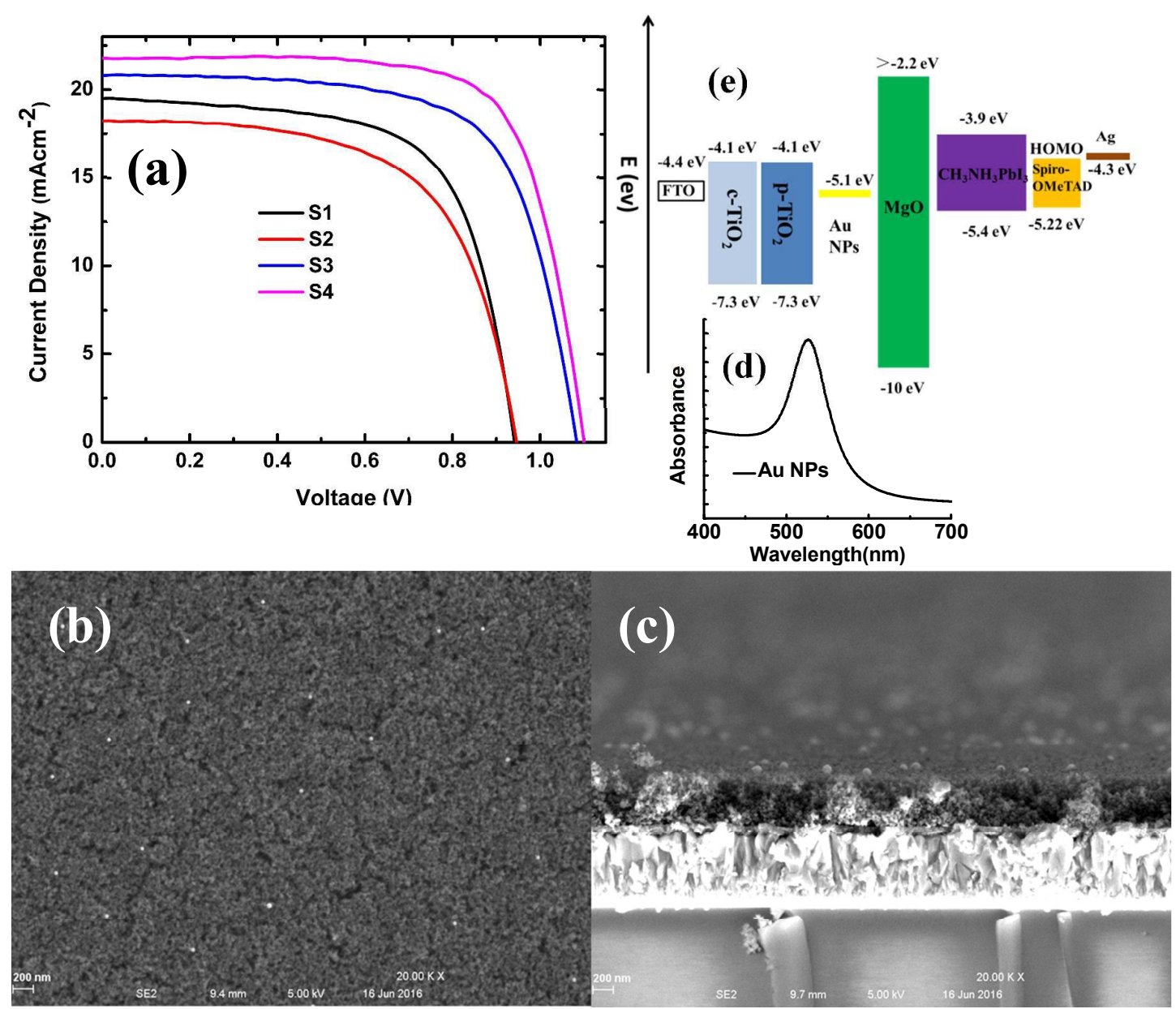

Fig. 1 (a) $J-V$ curves of perovskite solar cells based on p-TiO ${ }_{2}$ without and with $\mathrm{Au}$

$\mathrm{NP}$ and $\mathrm{MgO}$ coating. (b) FESEM image of the top surface morphology of the p- $\mathrm{TiO}_{2}$

layer containing $\mathrm{Au}$ NPs and (c) cross-sectional FESEM picture of the $\mathrm{p}-\mathrm{TiO}_{2}$

containing Au NPs. (d) Absorbance spectrum of Au suspension. (e) Energy diagram of materials for PSC devices with $\mathrm{Au} \mathrm{NP}$ and $\mathrm{MgO}$ modification. 
Table 1 Parameters of PSCs based on mesoporous $\mathrm{TiO}_{2}$ with and without Au NPs and $\mathrm{MgO}$ modification

\begin{tabular}{|cccll|}
\hline Device & $\mathrm{J}_{\mathrm{SC}}\left(\mathrm{mAcm}^{-2}\right)$ & $\mathrm{V}_{\mathrm{OC}}(\mathrm{V})$ & $\mathrm{FF}$ & $\eta(\%)$ \\
\hline $\mathrm{S} 1$ & 19.49 & 0.94 & 0.66 & 12.0 \\
\hline $\mathrm{S} 2$ & 18.21 & 0.95 & 0.62 & 10.7 \\
\hline $\mathrm{S} 3$ & 20.82 & 1.08 & 0.67 & 15.1 \\
\hline $\mathrm{S} 4$ & 21.76 & 1.09 & 0.68 & 16.1 \\
\hline
\end{tabular}

From Table 1, purely incorporating $\mathrm{Au}$ NPs between mesoporous $\mathrm{TiO}_{2}$ and perovskite greatly degraded the PV performance of the PSC device, especially its $\mathrm{J}_{\mathrm{SC}}$ and FF values. The PV variance and degradation may be due to two reasons. First, the $\mathrm{Au}$ NPs can be etched by the halide during the processing $\mathrm{CH}_{3} \mathrm{NH}_{3} \mathrm{PbI}_{3}$ absorber and the gold diffusion and migration into the perovskite material possibly take place in the thermal annealing treatment of the perovskite precursor films, causing detrimental and irreversible changes to the absorber. ${ }^{27-29} \mathrm{Au}$ migration into the perovskite material was found for PSC devices with metal contacts under thermal stress even at $70{ }^{\circ} \mathrm{C} .{ }^{28}$ This metal migration was observed to cause irreversible changes to the devices and in turn severely affected the device performance metrics. Second, the bare $\mathrm{Au}$ nanoparticles can act as charge recombination or trapping sites for light generated charge carriers due to the lower conduction energy level of the Au NPs than that of the $\mathrm{TiO}_{2}$ as shown in Fig. 1 (e). ${ }^{30,31}$ Comparing with the reference device (S1), device $\mathrm{S} 3$ with pure $\mathrm{MgO}$ modification exhibited enhanced $J_{\mathrm{SC}}, \mathrm{FF}$ and $V_{\mathrm{OC}}$ values. At the interface between $\mathrm{TiO}_{2}$ NPs and perovskite materials, the injected photo-induced electrons may recombine with holes. This would deteriorate the $J_{\mathrm{SC}}$ and the $V_{\mathrm{OC}}$ in 
PSC devices. The coating of n-type $\mathrm{p}-\mathrm{TiO}_{2}$ with ultrathin $\mathrm{MgO}$ dielectric shells is a general route to enhance the efficiency of solar cell devices. The introduced nanometer thick $\mathrm{MgO}$ interlayer acted as a "surface passivation layer" between the absorber and $\mathrm{TiO}_{2}$ to obstruct the recombination between photo-induced electrons and holes across the interface. The improved photocurrent, photovoltage and fill factor for photovoltaic devices employing an ultrathin $\mathrm{MgO}$ layer has been well known in DSSCs. ${ }^{32,33}$ Recently, MgO was successfully used as a blocking layer between compact or mesoporous $\mathrm{TiO}_{2}$ and perovskite layers to improve the cell performance. ${ }^{34-37}$ The increase of the open-circuit voltage of device S3 compared to device $\mathrm{S} 1$ can be mainly attributed to the much higher conduction band of $\mathrm{MgO}$ than that of $\mathrm{TiO}_{2}$, which would cause the conduction band of $\mathrm{TiO}_{2}$ to shift towards $\mathrm{MgO}$ and result in a higher quasi-Fermi level under illumination and a higher occ $^{34,38}$ Additionally, the ultrathin layer of $\mathrm{MgO}$ could act as a tunneling barrier that retards the back recombination from $\mathrm{TiO}_{2}$ to the hole transport material (HTM) in PSCs, thus, high $J_{\mathrm{sc}}$ and $\mathrm{FF}$ were obtained. ${ }^{34}$ Retarding of electron-hole recombination is also proved by electrochemical impedance spectroscopy (EIS). By incorporating both $\mathrm{Au}$ NPs and $\mathrm{MgO}$ in the PSC device, the PV performance was further improved. As a result, device S4 containing both Au NPs and MgO is superior to the other three types of PSC cells. The insulating MgO layer protected the $\mathrm{Au}$ NPs coated on the $\mathrm{p}-\mathrm{TiO}_{2}$ from corrosion or migration during the processing $\mathrm{CH}_{3} \mathrm{NH}_{3} \mathrm{PbI}_{3}$ absorber. The $\mathrm{MgO}$ film also prevented the direct contact between $\mathrm{Au}$ and the perovskite semiconductor, or the hole conductor spiro-OMeTAD in device S4, inhibiting an unwanted charge 
recombination pathway within the perovskite solar cell. $\mathrm{MgO}$ was found to change the surface state of $\mathrm{TiO}_{2}$ and worked as an insulating layer to reduce charge recombination as reported in Refs. 34-37. In our work, MgO coating have more functions. In addition to the roles reported in Refs. $34-37, \mathrm{MgO}$ coating acts as an insulating shell to protect Au NPs, make Au NPs intact and keep their structural and thermal stability during the following processing perovskite absorbers. Furthermore, compared with device S3 with pure $\mathrm{MgO}$ modification, device S4 exhibited similar $V_{\mathrm{OC}}$ and FF values, but significantly higher photocurrent. The increase of photocurrent in device S4 compared to device S3 suggested that localized surface plasmon resonance (LSPR) and electrical effects of Au NPs enhance the photovoltaic response of PSCs. ${ }^{39,40}$

To investigate the effects of $\mathrm{Au}$ NPs and $\mathrm{MgO}$ in PSC in detail, we measured optical absorption spectra as well as photoluminescence spectra of samples. As the PSC devices have different structures which would influence the interface between the perovskite absorber and the porous $\mathrm{TiO}_{2}$, it is expected to show different defect densities. The PL spectra were effective in exploring the recombination properties of light-excited electrons and holes in defected semiconductors. Fig. 2 shows the $\mathrm{UV}-\mathrm{Vis}$ and the PL spectra of $\mathrm{FTO} / \mathrm{c}-\mathrm{TiO}_{2} / \mathrm{p}-\mathrm{TiO}_{2} / \mathrm{CH}_{3} \mathrm{NH}_{3} \mathrm{PbI}_{3}$ samples without or with $\mathrm{Au}$ or $\mathrm{MgO}$ modification. At a glance, it is clear that there is no significant change in the absorption spectra of the four kinds of absorber samples. This may be due to the extraordinarily high absorption coefficient of hybrid perovskite 
$\mathrm{CH}_{3} \mathrm{NH}_{3} \mathrm{PbI}_{3}$ and the small amount of $\mathrm{Au}$ metal NPs or $\mathrm{MgO}$ loaded on $\mathrm{p}-\mathrm{TiO}_{2}$. From Fig. 2 (b), all absorber samples show emission peaks at about $762 \mathrm{~nm}$ (excitation wavelength $507 \mathrm{~nm}$ ), corresponding to an absorption onset at $\sim 760 \mathrm{~nm}^{41}$ The peak position of the emission was almost consistent within the four samples, however, the PL intensity changed a lot. Compared to the case of the reference absorber without any modification, the PL intensity of the absorber incorporated with bare Au NPs exhibited an obvious increasing tendency, whilst the PL intensity displayed a more and more intensely decreasing tendency from the sample with pure $\mathrm{MgO}$ to the one with both $\mathrm{Au}$ and $\mathrm{MgO}$ modification. Notably, the perovskite absorber sample with bare Au NPs exhibited the highest PL signal, and the corresponding PSC device was expected to show a higher recombination rate of carriers than the cells based on the other samples. In contrast, a significantly stronger degree of PL quenching for both perovskite samples with $\mathrm{MgO}$ coating using the magnesium salt was observed, confirming that electron extraction from perovskite to $\mathrm{TiO}_{2}$ NPs with $\mathrm{MgO}$ modification was more significant higher than to the pristine $\mathrm{TiO}_{2}$. The perovskite sample with both $\mathrm{Au}$ NP and $\mathrm{MgO}$ modification showed the lowest peak intensity and the most intense degree of PL quenching, a strong indication for the rapidest charge transfer, the most effective electron extraction and the least charge accumulation, and thus prospectively the highest short-circuit current and the best PV performance. ${ }^{42,43}$ Therefore, the inclusion of $\mathrm{Au} \mathrm{NPs}$ and $\mathrm{MgO}$ are unambiguously helpful for improvements in the ability for charge separation and collection, rapid charge transport, and enhanced photocurrent in the PSC device. 

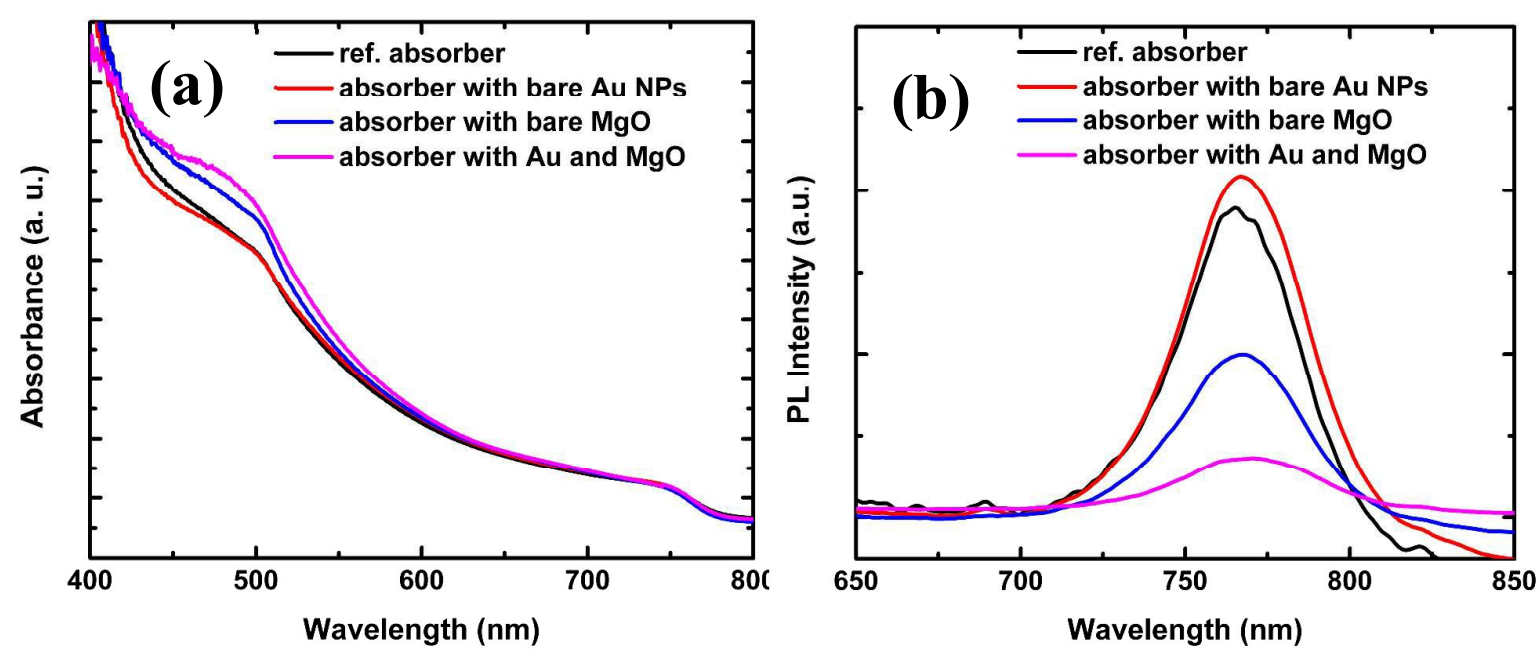

Fig. 2 (a) UV/Vis absorption and (b) PL spectra of p-TiO 2 -based perovskite absorbers without and with Au NPs and MgO coating.

The retarding charge recombination behavior of the formed PSC cells was studied by measuring their dark $J-V$ curves. Fig. 3 shows the measured dark $J$ - $V$ curves of the four structured PSC devices. As expected for device S3 and S4, MgO overlayer suppressed current almost at all biases, especially the dark cathodic recombination current at negative bias, compared to the case of the reference device (S1) without any modification. Device S2 with bare Au NPs showed the highest dark current value almost at all at all bias voltages, particularly at negative bias, because of the most intense charge carrier recombination. Recombination is one of the main factors limiting the cell performance. Device S4 with both $\mathrm{Au}$ NP and $\mathrm{MgO}$ modification showed the lowest dark current value at negative bias, demonstrating that combination use of $\mathrm{Au}$ NPs and $\mathrm{MgO}$ to modify porous $\mathrm{TiO}_{2}$ in the $\mathrm{CH}_{3} \mathrm{NH}_{3} \mathrm{PbI}_{3}$ absorbers is 
crucial in preventing leakage. The incorporating both and $\mathrm{Au}$ NPs and MgO effectively and significantly blocked charge carrier recombination and thus promisingly enhanced the PV performance of perovskite solar cells. The bias voltage at the minimal current density for the device is possibly attributed to the accumulation of space charges at interface due to mobile ions in $\mathrm{MgO} @ \mathrm{p}-\mathrm{TiO}_{2}$ based perovskite solar cells. $^{27,44}$

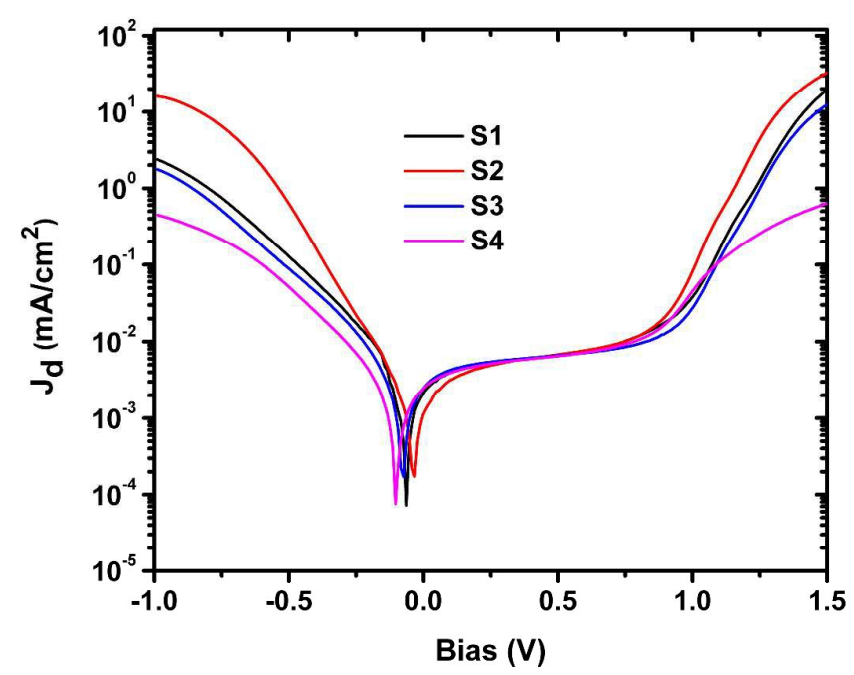

Fig. 3 Dark J-V curves of devices based on p- $\mathrm{TiO}_{2}$ without and with $\mathrm{Au}$ NP and $\mathrm{MgO}$ coating.

Electrochemical impedance spectroscopy (EIS) was used to characterize internal resistance and charge transfer kinetics of $\mathrm{p}-\mathrm{TiO}_{2}$ based perovskite solar cells without and with $\mathrm{Au} \mathrm{NP}$ or $\mathrm{MgO}$ modification. EIS measurements were performed for the four kinds of devices at a bias voltage of $0.9 \mathrm{~V}$ and in the dark. The measured Nyquist plot is shown in Fig. 4 (a). The structure of the PSC device could be considered as a leaking capacitor. ${ }^{45}$ The semicircle visually represents the recombination resistance at 
the interface of $\mathrm{TiO}_{2} /$ perovskite layer and $\mathrm{TiO}_{2} /$ hole transport layer. The bigger the diameter of the semicircle is, the less electron recombination at the interface. Moreover, the specific EIS results of PSCs can be estimated according to a simple equivalent circuit model shown in Fig. 4 (b), which has been widely applied for analyzing impedance spectroscopy of perovskite solar cells. ${ }^{45}$ It is characterized by a recombination resistance, $\mathrm{R}_{\mathrm{rec}}$, in parallel with a chemical capacitance, $\mathrm{C}_{\mathrm{rec}}$, and a hole transport resistance, $\mathrm{R}_{\mathrm{HTL}}$, in parallel with a chemical capacitance, $\mathrm{C}_{\mathrm{HTL}}$. The results of the impedance data are shown in Table 2. From Fig. 4(a) and Table 2, the device (S2) with bare Au NPs has the smallest semicircle, the minimal $R_{\text {rec }}\left(83.9 \Omega \cdot \mathrm{cm}^{2}\right)$, which indicates the lowest recombination resistance. The reference cell (S1) has the second lowest recombination resistance $\left(116.0 \Omega \cdot \mathrm{cm}^{2}\right)$. With pure $\mathrm{MgO}$ coated on the $\mathrm{TiO}_{2}$ NP layer (S3), the diameter of the semicircle dramatically increases, which indicates overwhelmingly higher recombination resistance $\left(375.0 \Omega \cdot \mathrm{cm}^{2}\right)$ in the device with pure $\mathrm{MgO}$ modification than devices S1 and S2. The Rrec value (292.0 $\Omega \cdot \mathrm{cm}^{2}$ ) of the PSC device containing both Au NPs and MgO is also much larger than the case of device $\mathrm{S} 1$ and $\mathrm{S} 2$, but a little smaller than that of device $\mathrm{S} 3$ with bare $\mathrm{MgO}$. Our EIS measurement results indicate that the recombination resistance was increased 2.5-3.2 times after $\mathrm{Au} @ \mathrm{MgO}$ or pure $\mathrm{MgO}$ modification, which led to a significantly decrease in current loss through recombination and increased the photocurrent and enhanced the FF for both device S3 and S4 as shown in Table 1. Additionally, from Fig. 4 (a) and Table 2, the four structured PSC devices exhibit different series resistance, $\mathrm{R}_{\mathrm{s}}$, due to contact effects. Device S4 and S2 show the first and second 
lowest series resistance Rs, respectively, indicating that addition of Au NPs can increase conductivity and improve the charge transport properties. Accordingly, the $\mathrm{J}_{\mathrm{SC}}$ value of device $\mathrm{S} 4$ is higher than that of $\mathrm{S} 3$, and hence device $\mathrm{S} 4$ shows the highest efficiency.

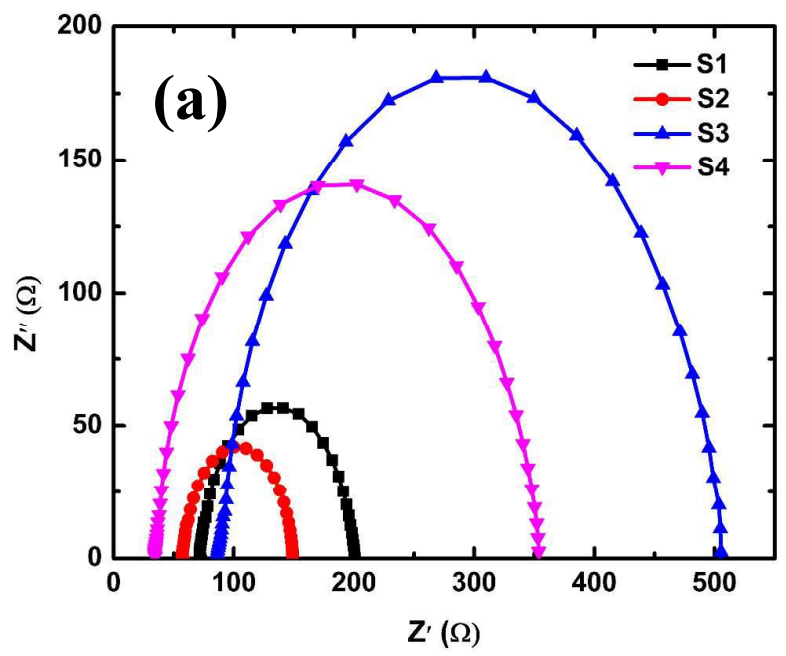

(b)

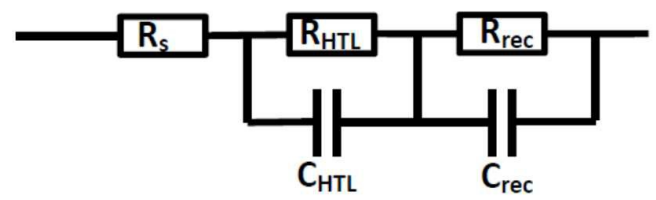

Fig. 4 (a) Nyquist plots of devices based on $\mathrm{p}-\mathrm{TiO}_{2}$ without and with $\mathrm{Au} \mathrm{NP}$ and $\mathrm{MgO}$ coating under dark condition at $0.9 \mathrm{~V}$ applied bias. (b) Simplified equivalent circuit to fit the impedance spectra.

Table 2 EIS results of PSCs based on mesoporous $\mathrm{TiO}_{2}$ with and without $\mathrm{Au}$ NPs and $\mathrm{MgO}$ modification.

\begin{tabular}{|ccccc|}
\hline Device & $\mathrm{R}_{\mathrm{s}}\left(\Omega \cdot \mathrm{cm}^{2}\right)$ & $\mathrm{R}_{\mathrm{rec}}\left(\Omega \cdot \mathrm{cm}^{2}\right)$ & $\mathrm{C}_{\mathrm{rec}}\left(\mathrm{mF} \cdot \mathrm{cm}^{-2}\right)$ & $\mathrm{R}_{\mathrm{HTL}}\left(\Omega \cdot \mathrm{cm}^{2}\right)$ \\
\hline $\mathrm{S} 1$ & 72.1 & 116.0 & 0.258 & 5.9 \\
\hline $\mathrm{S} 2$ & 57.0 & 83.9 & 0.255 & 2.9 \\
\hline $\mathrm{S} 3$ & 87.5 & 375.0 & 0.250 & 11.2 \\
\hline $\mathrm{S} 4$ & 34.5 & 292.0 & 0.254 & 5.4 \\
\hline
\end{tabular}


EQE is more pertinent than photocurrent-voltage measurement for studying optical and electrical responses of PSCs. EQE can be a product of light-harvesting efficiency, electron injection efficiency from excited perovskite $\mathrm{CH}_{3} \mathrm{NH}_{3} \mathrm{PbI}_{3}$ to $\mathrm{TiO}_{2}$ nanoparticles, and electron collection efficiency at the cathode in a mesoscopic $\mathrm{CH}_{3} \mathrm{NH}_{3} \mathrm{PbI}_{3} / \mathrm{TiO}_{2}$ heterojunction solar cell. The corresponding EQE spectra of the fabricated four types of PSC devices (S1-S4) are shown in Fig.5 (a). EQE depends on the absorption of light, the electron injection efficiency and the collection of charges. In order to emphasize the positive contribution of $\mathrm{Au} \mathrm{NPs}$ and $\mathrm{MgO}$ to the photocurrent, the EQE data of $\mathrm{Au}$ /or $\mathrm{MgO}$ modified PSCs were normalized by dividing that of the reference device, as shown in Fig. 5 (b). EQE of the PSC with pure $\mathrm{MgO}$ modification was significantly improved in the short wavelength region (320-600 nm) when compared with that of the pure $\mathrm{TiO}_{2}$ based device. This result is corresponded well with the increase of the $J_{\mathrm{SC}}$ data given in Table 1. But the EQE enhancement of the pure $\mathrm{MgO}$ modified device basically decreased with the increase of the wavelength from $320 \mathrm{~nm}$, and the EQE value at wavelength longer than about $750 \mathrm{~nm}$ was even lower than that of the reference cell. For an absorber semiconductor, the absorption coefficient, $\alpha$, is related to the extinction coefficient, $\mathrm{k}$, by $\alpha=4 \pi \mathrm{k} / \lambda$, where $\lambda$ is the wavelength. The absorption depth, $l$, is given by $l=\lambda /(\mathrm{p} 4 \pi \mathrm{k})$, where $\mathrm{p}$ is the porosity, which is $\sim 0.5$ for the mesoporous $\mathrm{CH}_{3} \mathrm{NH}_{3} \mathrm{PbI}_{3}$ layer and 1.0 for the perovskite capping layer. Light absorption depth of the absorber as a function of the light wavelength is shown in Fig. 5 (c). Photon capture is not as high in the range of $600 \mathrm{~nm}<\lambda<800 \mathrm{~nm}$ as it is for shorter wavelengths because the extinction 
coefficient rapidly decays for red frequencies. The thickness of the mesoporous layer in our devices is about $400 \mathrm{~nm}$. The incident light at the longer wavelength (>650 nm) is partially absorbed in the perovskite capping layer and the generated electron-hole pairs have to travel the greater distance to the surface of the networked $\mathrm{TiO}_{2} \mathrm{NPs}$ in the mesoporous layer, which makes it more difficult for electron injection into the insulator $\mathrm{MgO}$ coated $\mathrm{TiO}_{2}$. As a result, the EQE spectrum of the device covered by $\mathrm{MgO}$ was lower than that of the reference in the long wavelength region $(>750 \mathrm{~nm})$. In contrast, EQE of the cell using bare Au NPs was considerably decreased in the short wavelength region (320-600 nm), as shown in Figs. 5 (a) and (b). However, the PSC containing both Au NPs and MgO achieved significant EQE enhancement across the whole UV-Vis- near infra-red (NIR) region (320- $800 \mathrm{~nm})$ than the cell based on pure $\mathrm{TiO}_{2}$. The EQE enhancement in the whole UV-Vis-NIR regime induced the prominent increase in $J_{\mathrm{SC}}$ for device S4. From Figs. 5 (a) and (b), the trend in EQE enhancement for differently structured PSC devices is also consisted with that from $J-V$ measurement and analysis shown in Figure 1 and Table 1.
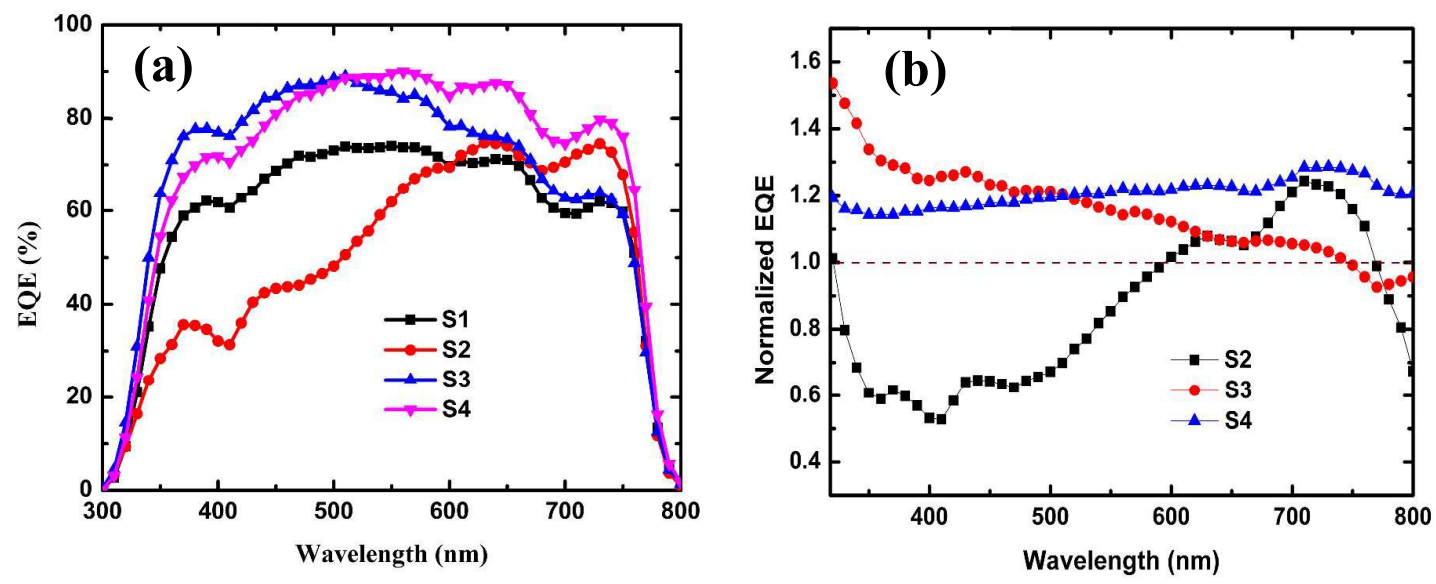


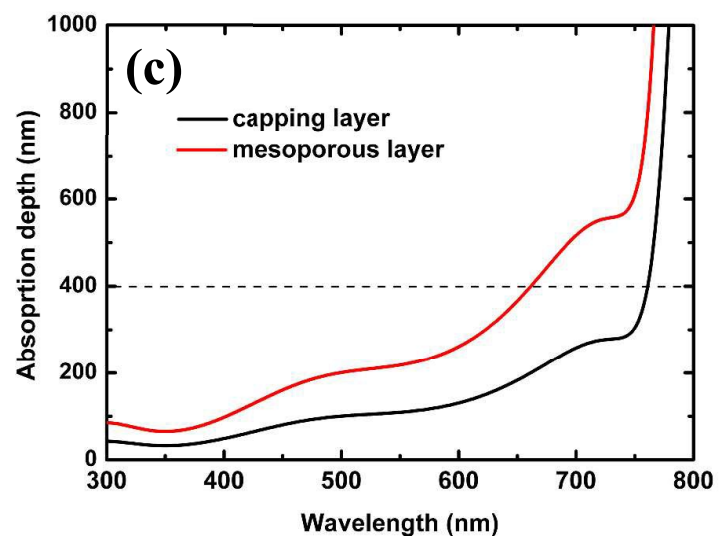

Fig.5 (a) EQE spectra and (b) normalized EQE curves of devices based on $\mathrm{p}-\mathrm{TiO}_{2}$ without and with Au NPs and MgO coating. (c) Calculated absorption depth as a function of wavelength.

As compared to bare $\mathrm{Au}$ NPs, Au NPs with insulating $\mathrm{MgO}$ shells have better structural and thermal stability, in particular retarding the corrosion of Au NPs by the halide, preventing charge trapping site formation or Oswald ripening ${ }^{46}$ and enabling thermal processing of high-quality perovskite absorbers during the device fabrication. More importantly, from the standpoint of $\mathrm{Au} \mathrm{NPs}$, the insulating $\mathrm{MgO}$ coating prevents direct contact between $\mathrm{Au}$ and the perovskite, or the hole conductor spiro-OMeTAD, inhibiting an unwanted charge recombination pathway within the devices, while from the point of porous $\mathrm{TiO}_{2}$, ultra-thin $\mathrm{MgO}$ coating on porous $\mathrm{TiO}_{2}$ effectively blocks the charge recombination at the $\mathrm{TiO}_{2} / \mathrm{CH}_{3} \mathrm{NH}_{3} \mathrm{PbI}_{3}$ interface in perovskite solar cells, thereby extending the carrier lifetime and improving $J_{\mathrm{SC}}$ and $V_{\mathrm{OC}}$ values of the PSC device. ${ }^{34,35}$ As a result, employment of both Au NPs and MgO in the $\mathrm{CH}_{3} \mathrm{NH}_{3} \mathrm{PbI}_{3}$ absorbers effectively and significantly enhanced $J_{\mathrm{SC}}, V_{\mathrm{OC}}$ and 
EQE values of perovskite solar cells.

Generally, metal nanoparticles could enhance the light energy capture in the solar cell by either scattering light enabling a longer optical path-length, by a dipole-dipole interaction and resonant energy transfer or by near-field coupling between the surface plasmon polariton and the absorber excited state. Two classic processes, i.e., light absorption increase by LSPRs ${ }^{15-21,26}$ and hot-electron injection, ${ }^{25,}$ 47- 49 have been widely reported for plasmon-enhanced solar energy harvesting. In the field of perovskite solar cells, Snaith and co-workers first reported plasmonic enhancement in perovskite solar cells in $2013 .^{22}$ They mixed core-shell Au@SiO $\mathrm{SiO}_{2}$ NPs into $\mathrm{Al}_{2} \mathrm{O}_{3}$ paste to prepare mesoporous $\mathrm{Al}_{2} \mathrm{O}_{3}$ scaffold, delivering a $\mathrm{CH}_{3} \mathrm{NH}_{3} \mathrm{PbI}_{3-\mathrm{x}} \mathrm{Cl}_{\mathrm{x}}$ device efficiency up to $11.4 \%$. Compared to the control device, the photocurrent density of the device containing $\mathrm{Au} @ \mathrm{SiO}_{2}$ NPs was improved by 14.5\%. The authors have systemically carried out time-resolved and steady state photoluminescence (PL) measurements of the peroskite absorber with and without $\mathrm{Au} @ \mathrm{SiO}_{2} \quad \mathrm{NPs}$. The obtained enhancement in device performance was attributed to a three-fold reduction in exciton binding energy (EB) of the perovskite in the presence of Ag LSPR. Two years later, Snaith and co-workers blended core-shell $\mathrm{Ag} @ \mathrm{TiO}_{2} \mathrm{NPs}_{\text {into }} \mathrm{Al}_{2} \mathrm{O}_{3}$ paste to prepare mesoporous $\mathrm{Al}_{2} \mathrm{O}_{3}$ scaffold, boosting the $\mathrm{CH}_{3} \mathrm{NH}_{3} \mathrm{PbI}_{3-\mathrm{x}} \mathrm{Cl}_{\mathrm{x}}$ device efficiencies by $12.4 \%{ }^{23}$ Their photon-to-current conversion efficiency (IPCE) measurements revealed broad-band enhancement over the entire absorption spectrum, rather than in the spectral region of the Ag nanoparticle LSPR. Small changes in the 
exciton EB cannot be expected to result in significant changes of photocurrent generation in the solar cell. The authors developed a theoretical model, which predicts that the presence of highly polarizable nanoparticles enhances the radiative decay of excitons and increases the reabsorption of emitted radiation, presenting a novel photon recycling scheme for enhancing the PSC performance. In another study, ${ }^{25} \mathrm{Au}$ nanoparticles were inserted into a compact TiOx layer, resulting in a $20 \%$ increase in Spiro-OMeTAD HTM based planer heterojunction $\mathrm{CH}_{3} \mathrm{NH}_{3} \mathrm{PbI}_{3-\mathrm{x}} \mathrm{Cl}_{\mathrm{x}}$ solar cell. Improvements in $\mathrm{J}_{\mathrm{SC}}, \mathrm{V}_{\mathrm{OC}}$ and $\mathrm{FF}$ were attributed to plasmon-mediated hot carrier injection from $\mathrm{Au}$ NPs to $\mathrm{TiOx}$. In a recent study, ${ }^{26} \mathrm{Au}$ decorated $\mathrm{TiO}_{2}$ nanofibers by an electro-spinning technique were applied to assemble mesoscopic $\mathrm{CH}_{3} \mathrm{NH}_{3} \mathrm{PbI}_{3}$ perovskite solar cells. The PSC with pure $\mathrm{TiO}_{2}$ nanofibers shows an efficiency of $11.16 \%$, while the device with $\mathrm{Au}$ decorated $\mathrm{TiO}_{2}$ nanofibers achieves an efficiency of $14.92 \%$. This improvement was attributed to the enhancement of light absorption by LSPR and reduced charge recombination in $\mathrm{Au} @ \mathrm{TiO}_{2}$ nanofiber electrodes. Therefore, the type of metal nanostructures used (shape, size, composition, shell control) and their precise location with respect to the perovskite in solar cells as well as the kind of perovskites impact device performance enhancements. Moreover, the spontaneous polarization of perovskite crystals adds both complexity and potential for energy harvesting. Deeper understanding of the fundamental interactions between plasmonic nanostructures and perovskites is required for future optimization of both the light harvesting abilities and charge transport mechanisms in PSCs. 
In our work, no significantly distinct difference was observed in absorption pattern of the fabricated four types of PSC devices, as shown in Fig. 2 (a), nevertheless, the EQE enhancement was achieved over the whole range, including the UV-Vis $(320 \mathrm{~nm}$ to $500 \mathrm{~nm})$ and NIR wavelength range (500 to $800 \mathrm{~nm}$ ) for the device doped with $\mathrm{Au}$ and $\mathrm{MgO}$, rather than following in the spectral region of the $\mathrm{Au}$ nanoparticle localized surface plasmon resonances shown in Fig. 1 (d). Therefore, the EQE and PV performance enhancements for $\mathrm{Au} @ \mathrm{MgO}$ devices could not directly be associated with the optical spectrum of the $\mathrm{Au} @ \mathrm{MgO}$ nanoparticles. To investigate the roles of $\mathrm{Au}$ NPs and $\mathrm{MgO}$ shell in the observed EQE and photocurrent, photovoltage and PCE improvements in the plasmonic PSC cells, finite-difference time-domain (FDTD) numerical simulations were performed for the geometry shown in Fig. 6 (a). The PSC is with a structure of glass (50)/FTO(100)/c- $\mathrm{TiO}_{2}(40) / \mathrm{p}-\mathrm{TiO}_{2}+$ $\mathrm{Au}$ spheres $+\mathrm{MgO}+\mathrm{MAPbI}_{3}(300) /$ spiro-MeOTAD(100)/ $\operatorname{Ag}(30)$. The numbers in parentheses indicate the layer thicknesses in nanometers. The thickness of $\mathrm{MgO}$ is 2 nm. The size of $\mathrm{TiO}_{2}$ spheres (yellow color) in the $\mathrm{p}-\mathrm{TiO}_{2}$ is $10 \mathrm{~nm}$ in diameter, the spacing between $\mathrm{TiO}_{2} @ \mathrm{MgO}$ spheres is $1 \mathrm{~nm}$, and the gaps are filled by $\mathrm{MAPbI}_{3}$. In order to see the $\mathrm{TiO}_{2}$ spheres, the colors of both $\mathrm{MAPbI}_{3}$ (light blue color) and $\mathrm{MgO}$ shell (light green color) is half transparent. There is a single $\mathrm{Au} @ \mathrm{MgO}$ sphere positioned at the top of $\mathrm{p}-\mathrm{TiO}_{2} @ \mathrm{MgO}$ and embedded in $\mathrm{MAPbI}_{3}$ capping layer. The diameter of the Au sphere (red color) is $40 \mathrm{~nm}$. The optical properties (refractive index, $\mathrm{n}$ and extinction coefficient, $\mathrm{k}$ ) of materials are from the data in previous publications. ${ }^{50,51}$ A commercial FIT software package (CST Microwave Studio 2006) 
was used with Cartesian grids system (FDTD module). ${ }^{21,52,53}$

The boundary conditions along $x$ and $y$ axis is set to be 'periodic'. Upon choosing periodic boundary setting and a suitably refined computational grid (the maximum grid length was chosen as wavelength / 300 in the paper) in the simulation software, the corresponding numerical solution gives an accurate representation of the dynamics of the electromagnetic field. The Au sphere@ $\mathrm{MgO}$ is placed along the $\mathrm{z}$ coordinate as shown in Fig. 6 (a). The origin of the coordinates is taken at the center of the $\mathrm{Au}$ sphere. The $x y$ plane is set parallel to the surface of the glass substrate. Let the plane-wave electromagnetic field of wave vector $k$ be incident from the bottom surface of the glass substrate. The wave propagates along the $\mathrm{z}$ coordinate, the electric vector is along the $x$ coordinate, and the magnetic vector along the $y$ coordinate.

Figs. 6 (b) and (c) show the calculated local amplitude enhancement distribution of the electric field $|E|$ in the $x z$ plane at $\mathrm{y}=0$ for an incident wave with a wavelength of $560 \mathrm{~nm}$ or $730 \mathrm{~nm}$, respectively. The maximal EQE value was obtained at $560 \mathrm{~nm}$, and the maximal EQE enhancement was achieved at $730 \mathrm{~nm}$ as shown in Figs. 5 (a) and (b). The circumferences of the $\mathrm{Au} @ \mathrm{MgO}$ and p- $\mathrm{TiO}_{2} @ \mathrm{MgO}$ spheres can be seen clearly from the calculated figures. The electric field is only slightly enhanced and localized around the $\mathrm{Au}$ sphere, and the maximum $|\mathrm{E}|$ enhancement factor is only about 1.5 at $560 \mathrm{~nm}$. Differently, the electric field is significantly enhanced and 
localized around the $\mathrm{Au}$ sphere, and the maximum $|\mathrm{E}|$ enhancement factor is up to 22.8 at $730 \mathrm{~nm}$.

Figs. $6(\mathrm{~d})-(\mathrm{g})$ show the simulated power flow within the $x z$ planes at $\mathrm{y}=0,10$ $\mathrm{nm}$ for wavelengths of $560 \mathrm{~nm}$ and $730 \mathrm{~nm}$, respectively. The positions of the $\mathrm{Au} @ \mathrm{MgO}$ and p-TiO2@MgO spheres can be observed clearly from the figures. For the incident visible light with a wavelength of $560 \mathrm{~nm}$, the power flow successively passes through $\mathrm{TiO}_{2} @ \mathrm{MgO} \mathrm{NPs}$, the filled perovskite semiconductor, $\mathrm{Au} @ \mathrm{MgO}$ and perovskite capping layer with some deflections from the $\mathrm{z}$ coordinate around the surface of the Au sphere as shown in Figs. 6 (d) and (e). When the light with a wavelength of $730 \mathrm{~nm}$ is normally incident on the PSC device, the wave almost straight passes through $\mathrm{TiO}_{2} @ \mathrm{MgO} \mathrm{NPs}$ and the filled perovskite semiconductor along the $\mathrm{z}$ coordinate. But, after the porous layer, the straight propagation of light power flow is replaced by complex whirls and circulates round the Au spheres and the perovskite in the capping layer as shown in Figs. 6 (f) and (g). The simulated power flow within the $x y$ planes at $z=0,18 \mathrm{~nm}$ is shown in Figs. $6(\mathrm{~h})$ and $(\mathrm{k})$ for the wavelength of $730 \mathrm{~nm}$. The relative positions of the p- $\mathrm{TiO}_{2} @ \mathrm{MgO}$ spheres can be seen in the background. The red circle indicates the position of the $\mathrm{Au} @ \mathrm{MgO}$ sphere. For the incident red light along the positive $z$ coordinate, the $\mathrm{Au} @ \mathrm{MgO}$ sphere array manipulates the flow of the red energy and partially guides the red light into the $x y$ plane of the absorber film in nanoscale and near-field regions, and as a result, some red energy flows parallel to the $x y$ plane, more clearly shown in Fig. $6(\mathrm{k})$. The light 
energy passing through the absorber perovskite surrounding the Au sphere will be redirected toward the $\mathrm{Au}$ sphere, absorbed by the $\mathrm{Au}$, and then, the light energy is transferred back to the perovskite material, as clearly shown in Figs. 6 (f) and (g). The Au NP absorbs lights via some portion of its surfaces, and then re-radiates energy into the absorber via other parts of the surfaces. Light power flows could circulate the near-field areas for multiple rounds due to interference of scattered and incident lights. $^{54}$

The above calculation results indicate that the $\mathrm{Au} @ \mathrm{MgO}$ sphere array in the PSC device can modulate and deflect the energy flow direction in dipole-dipole coupling. This energy flow regulation can open a process which is different from the widely reported light absorption enhancement by LSPRs ${ }^{15-21,26}$ or hot-electron injection ${ }^{25,}$, 47${ }^{49}$ for plasmon-enhanced solar energy harvesting. In the this case, the plasmonic metal absorbs sunlight, converts the absorbed energy into localized surface plasmon resonance oscillations and transfers the plasmonic energy to the perovskite semiconductor via resonant energy transfer, which generates electron-hole pairs below and near the perovskite band edge $\mathrm{e}^{55,56}$ and enhances the efficiency of the incident photon-to-electron conversion process for red frequencies in perovskite solar cells shown in Table 1 and Figs. 5 (a) and (b). Furthermore, we think that the photon management by use of $\mathrm{Au}$ NPs and $\mathrm{MgO}$ shell to minimize photonic and energy losses in the PSC device also offers promising scenarios for employing photon recycling to improve photoconversion efficiencies of perovskite solar cells..$^{23,57-59}$ In 
our plamonic PSC device, energy transport is not limited by diffusive carrier transport but can occur over long distances through multiple absorption-emission events. Photons are reabsorbed and re-emitted many times before an electron-hole pair is collected or a luminescent red photon escapes. Pazos-Outón et al. show that lead halide materials have luminescence properties similar to those of $\mathrm{GaAs}^{57}$ and may, thus, also reach super high conversion efficiencies as GaAs semiconductor materials. The presence of Au NPs enhances the radiative decay of excitons in the perovskite absorber $^{23}$. The Au@MgO nanoparticles could work as antennas for the excitonic dipoles. The radiated photons from exciton decay would then have a dramatically prolonged optical path length due to the energy flow regulatory benefit of the $\mathrm{Au}$ nanospheres shown in Figs. 6 (f)-(k). By this means the reabsorption from reemitted light is enhanced, in essence enabling photon recycling with a much greater efficiency and driving the enhanced EQE and photocurrent in perovskite solar cells with the addition of $\mathrm{Au}$ nanoparticles and $\mathrm{MgO}$ compared to the case modified only with pure MgO. ${ }^{23,57-59}$ Higher photon densities also lead to higher internal luminescence and a buildup of excited charges, which increase the split of quasi-Fermi levels and enhance the achievable open-circuit voltage in a solar cell. ${ }^{57,60}$ Finally, introducing Au NPs in $\mathrm{TiO}_{2}$ photoanodes of PSCs can increase the charge transport capability as demonstrated in Fig. 4 (a) and Table 2. As a result, employment of both Au NPs and $\mathrm{MgO}$ in the $\mathrm{CH}_{3} \mathrm{NH}_{3} \mathrm{PbI}_{3}$ absorbers effectively and significantly enhanced EQE, $J_{\mathrm{SC}}$ and hence PCE values of perovskite solar cells compared to the case modified only with pure $\mathrm{MgO}$ shown in Table 1. 

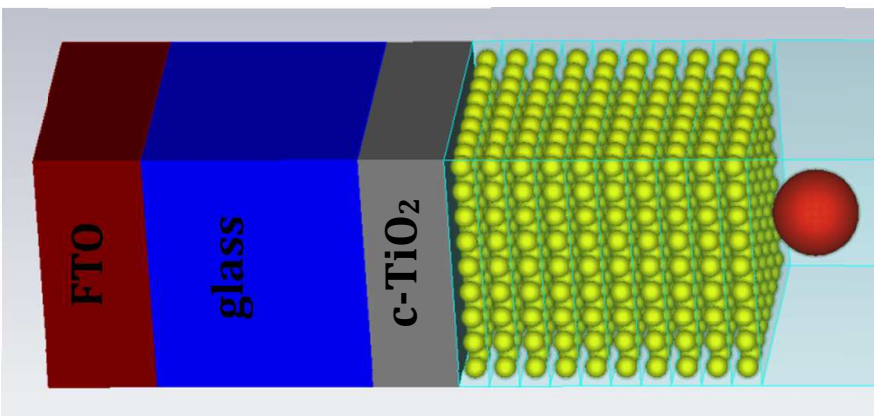

(a)
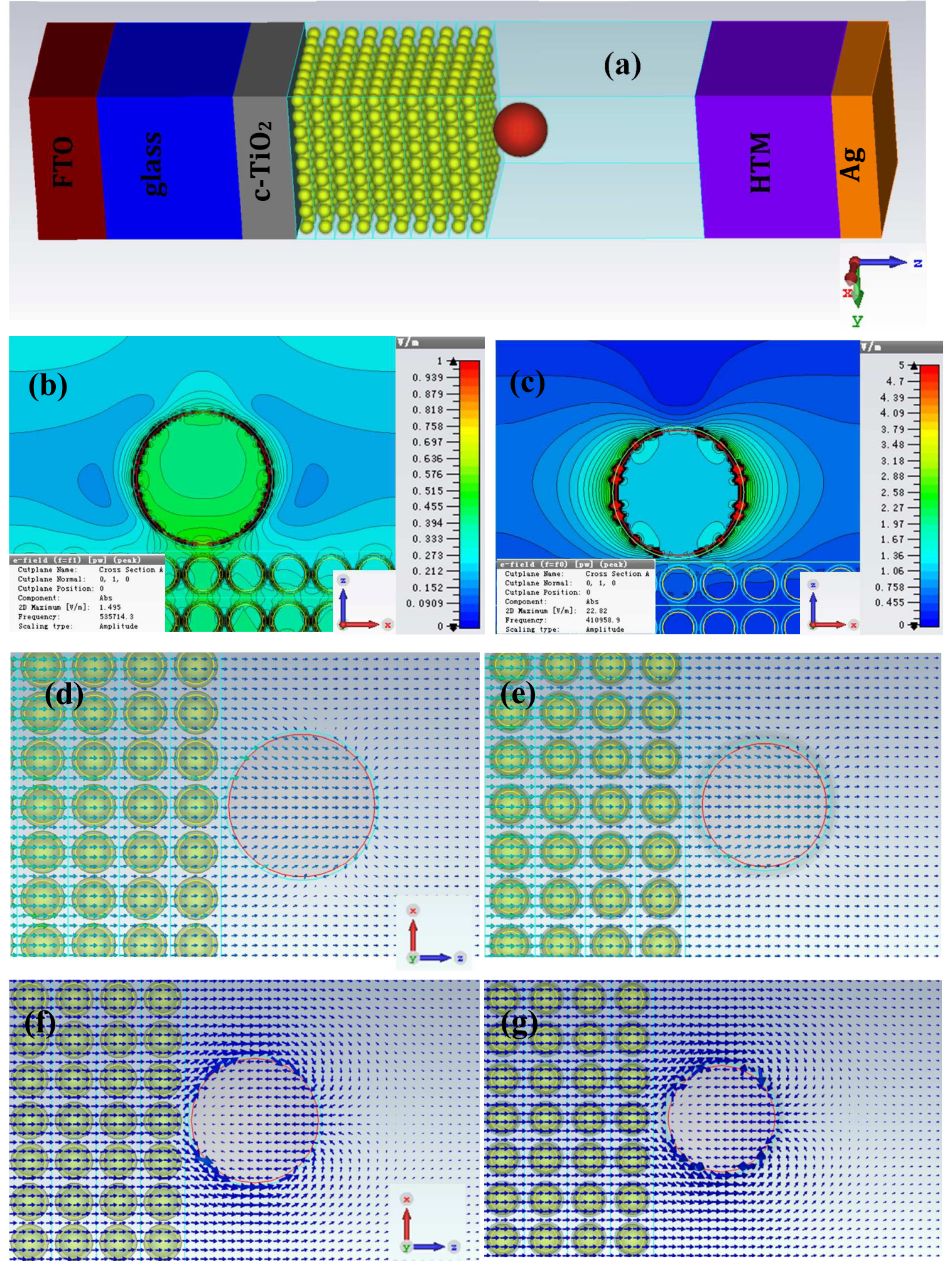

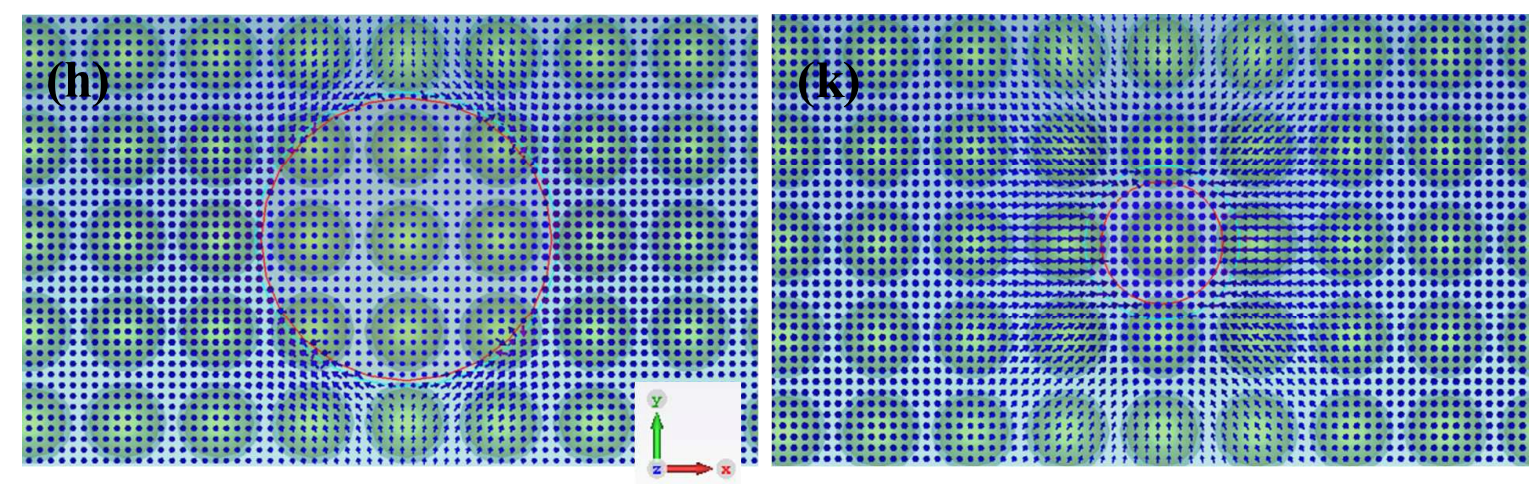

Fig.6 (a) Model of device modified with both Au NPs and MgO. 2D field

$|E|$ enhancement distribution image in the xz planes at (b) $\mathrm{y}=0 \mathrm{~nm}, \lambda=560 \mathrm{~nm}$, (c) $\mathrm{y}=$

$0 \mathrm{~nm}, \lambda=730 \mathrm{~nm}$. Power flow diagrams within the $x z$ planes at (d) $\mathrm{y}=0 \mathrm{~nm}, \lambda=560$

$\mathrm{nm}$, (e) $\mathrm{y}=10 \mathrm{~nm}, \lambda=560 \mathrm{~nm}$, (f) $\mathrm{y}=0 \mathrm{~nm}, \lambda=730 \mathrm{~nm},(\mathrm{~g}) \mathrm{y}=10 \mathrm{~nm}, \lambda=730 \mathrm{~nm}$.

Power flow diagrams within the $x y$ planes at $(\mathrm{h}) \mathrm{z}=0 \mathrm{~nm}, \lambda=730 \mathrm{~nm},(\mathrm{~g}) \mathrm{z}=18 \mathrm{~nm}$,

$$
\lambda=730 \mathrm{~nm} .
$$

The stability of perovskite solar cells is a major issue restricting the terrestrial applications. We investigated the stability of unsealed PSCs based on mesoporous $\mathrm{TiO}_{2}$ with and without $\mathrm{Au}$ NPs and $\mathrm{MgO}$ modification under UV irradiation. The PSCs were exposed to $365 \mathrm{~nm}$ UV illumination with an intensity of $90 \mathrm{mWcm}^{-2}$, and removed at certain time intervals to measure the $\mathrm{J}-\mathrm{V}$ curves under simulated AM1.5 $100 \mathrm{mWcm}^{-2}$ irradiance. In Fig. 7 we observe that device $\mathrm{S} 3$ and $\mathrm{S} 4$ exhibit significantly improved stability. Their PCE remains more than $85 \%-90 \%$ of its initial value even after 15 min UV irradiation in air. By contrast, device S2 with bare $\mathrm{Au}$ NPs cannot endure the UV irradiation test and shows nearly zero PCE just after $1 \mathrm{~min}$ 
UV irradiation, and the control device (S1) exhibits only $35 \%$ of its initial value after 9 min UV illumination under the same UV testing conditions. When $\mathrm{TiO}_{2}$ based PSCs are exposed to UV light exposure, photo generated holes in the mesoporous $\mathrm{TiO}_{2}$ react with oxygen absorbed at surface oxygen vacancies, which then become deep traps leading to charge recombination, resulting in a drop off in PV performance of the device. ${ }^{61}$ Additionally, the UV light absorbed by $\mathrm{TiO}_{2}$ would catalyze the decomposition of $\mathrm{CH}_{3} \mathrm{NH}_{3} \mathrm{PbI}_{3}$ to $\mathrm{PbI}_{2}$, forming non-radiative defect sites within the perovskite and especially at the $\mathrm{TiO}_{2}$ /perovskite interface and degrading the $\mathrm{PV}$ performance of the device. ${ }^{62,63}$ The presence of bare Au NPs in the PSC device dramatically accelerated the UV degradation, and the device with bare Au NPs deteriorated to zero efficiency in 2 min. These UV light effects can be avoided by depositing nanometer thick passivation layer onto the $\mathrm{TiO}_{2}$ to prevent contact between $\mathrm{TiO}_{2}$ and $\mathrm{CH}_{3} \mathrm{NH}_{3} \mathrm{PbI}_{3}$, decrease the photocatalytic properties of the $\mathrm{TiO}_{2}$ and reduce electronic defect density at the $\mathrm{TiO}_{2}$ /perovskite interface. It was reported that light stability of PSC devices was obviously improved by using $\mathrm{CsBr}$ as an interface modifier for the $\mathrm{c}-\mathrm{TiO}_{2}{ }^{62}$ or employing $\mathrm{Sb}_{2} \mathrm{~S}_{3}$ as the insulating layer between mesoporous $\mathrm{TiO}_{2}$ and perovskite layers. ${ }^{63}$ In our work, we have demonstrated that by incorporating both $\mathrm{Au}$ NPs and insulating $\mathrm{MgO}$ onto mesoporous $\mathrm{TiO}_{2}$ a significant improvement of the UV stability in the perovsikite solar cell is achieved. 


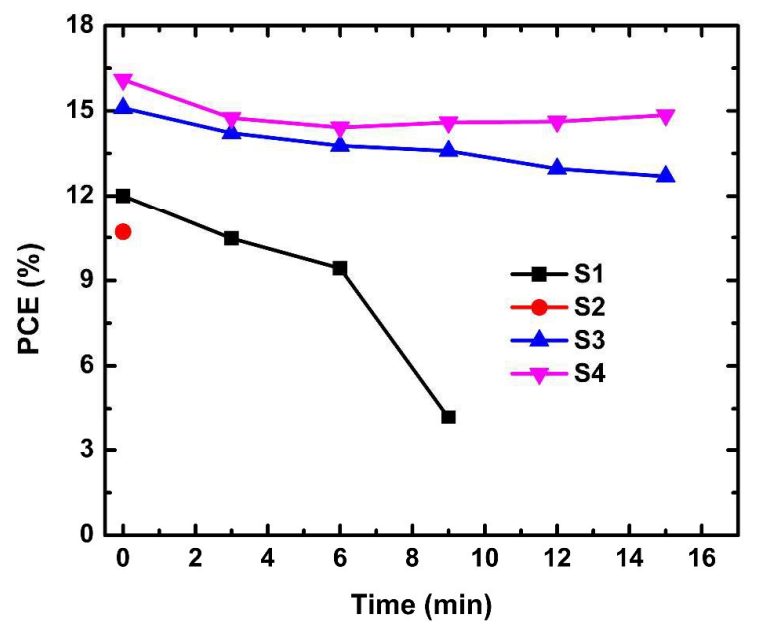

Fig. 7 Power conversion efficiency variation of unsealed PSCs based on mesoporous $\mathrm{TiO}_{2}$ with and without $\mathrm{Au}$ NPs and $\mathrm{MgO}$ modification at $~ 55 \%$ humidity after various UV exposure durations $\left(90 \mathrm{mWcm}^{-2}\right.$ at $\left.365 \mathrm{~nm}\right)$ durations.

\section{CONCLUSIONS}

A facile and effective method has been investigated to achieve efficient performance perovskite devices with simultaneously high open circuit voltage and high short circuit current density by combinational use of Au NPs and insulating MgO. Purely incorporating $\mathrm{Au}$ NPs between mesoporous $\mathrm{TiO}_{2}$ and perovskite capping layer greatly degraded the PV performance of the PSC device from $12.0 \%$ to $10.7 \%$. By employing a pure $\mathrm{MgO}$ nanolayer, the power conversion efficiency was increased from $12.0 \%$ to $15.1 \%$. By combinational use of $\mathrm{Au}$ NPs and $\mathrm{MgO}$ passivation layer, a high power conversion efficiency of $16.1 \%$ with both high open circuit voltage of $1.09 \mathrm{~V}$ and high short-circuit current density of $21.76 \mathrm{~mA} \mathrm{~cm}^{-2}$ was obtained. The photovoltage, photocurrent and efficiency values were $16.0 \%, 11.6 \%$ and $34.2 \%$ higher than the pure $\mathrm{TiO}_{2}$ based perovskite solar cells. The enhancement could be 
associated with the effective photon management by use of Au NPs and MgO shell to minimize photonic and energy losses for the generation of carriers, the high charge transport capability and the low charge recombination losses in perovskite solar cells. Moreover, combinational use of $\mathrm{Au}$ NPs and $\mathrm{MgO}$ passivation layer effectively enhanced the stability of PSC devices under UV light soaking. The fundamental optics and physics behind regulation of energy flow in perovskite solar cell and concept of using $\mathrm{Au}$ nanoparticles and $\mathrm{MgO}$ to improve the device performance has been explored. Theoretical electromagnetic calculations supported the experimental plasmon-enhanced energy conversion efficiency results of perovskite solar cells in combination with $\mathrm{Au}$ NPs and $\mathrm{MgO}$ coating.

\section{ACKNOWLEDGEMENTS}

This work was supported by the National Natural Science Foundation of China (Nos. 11274119 and 61275038) and the Large Instruments Open Foundation of East China Normal University. 


\section{REFERENCES}

1. A. Kojima, K. Teshima, Y. Shirai and T. Miyasaka, Organometal Halide Perovskites as Visible-Light Sensitizers for Photovoltaic Cells, J. Am. Chem. Soc., 2009, 131, 6050-6051.

2. M.M. Lee, J. Teuscher, T. Miyasaka, T.N. Murakami and H.J. Snaith, Supporting Material: Efficient hybrid solar cells based on meso-superstructured organometal halide perovskites, Science, 2012, 338, 643.

3. N.J. Jeon, J.H. Noh, W.S. Yang, Y.C. Kim, S. Ryu, J. Seo and I.S. Sang, Compositional engineering of perovskite materials for high-performance solar cells, Nature, 2015, 517, 476-480.

4. M.K. Nazeeruddin, In retrospect: Twenty-five years of low-cost solar cells, Nature, 2016, 538, 463-464.

5. G.E. Eperon, S.D. Stranks, C. Menelaou, M.B. Johnston, L.M. Herz and H.J. Snaith, Formamidinium lead trihalide: a broadly tunable perovskite for efficient planar heterojunction solar cells, Energ. Environ. Sci., 2014, 7, 982-988.

6. N.K. Noel, S.D. Stranks, A. Abate, C. Wehrenfennig, S. Guarnera, A.-A. Haghighirad, A. Sadhanala, G.E. Eperon, S.K. Pathak and M.B. Johnston, Lead-free organic-inorganic tin halide perovskites for photovoltaic applications, Energ. Environ. Sci., 2014, 7, 3061-3068.

7. J. Burschka, N. Pellet, S.-J. Moon, R. Humphry-Baker, P. Gao, M.K. Nazeeruddin and M. Grätzel, Sequential deposition as a route to high-performance perovskite-sensitized solar cells, Nature, 2013, 499, 316-319.

8. Z. Xiao, C. Bi, Y. Shao, Q. Dong, Q. Wang, Y. Yuan, C. Wang, Y. Gao and J. Huang, Efficient, high yield perovskite photovoltaic devices grown by interdiffusion of solution-processed precursor stacking layers, Energ. Environ. Sci., 2014, 7, 2619-2623.

9. Q. Chen, H. Zhou, Z. Hong, S. Luo, H.-S. Duan, H.-H. Wang, Y. Liu, G. Li and Y. Yang, Planar heterojunction perovskite solar cells via vapor-assisted solution process, J. Am. Chem. Soc., 2013, 136, 622-625. 
10. M. Liu, M.B. Johnston and H.J. Snaith, Efficient planar heterojunction perovskite solar cells by vapour deposition, Nature, 2013, 501, 395-398.

11. N.J. Jeon, J.H. Noh, Y.C. Kim, W.S. Yang, S. Ryu and S.I. Seok, Solvent engineering for high-performance inorganic-organic hybrid perovskite solar cells, Nat. Mater., 2014, 13, 897-903.

12. C. Zhang, Y. Luo, X. Chen, Y. Chen, Z. Sun and S.M. Huang, Effective Improvement of the Photovoltaic Performance of Carbon-Based Perovskite Solar Cells by Additional Solvents, Nano-Micro. Lett., 2016, 8, 347-357.

13. M. Saliba, T. Matsui, J.-Y. Seo, K. Domanski, J.-P. Correa-Baena, M.K. Nazeeruddin, S.M. Zakeeruddin, W. Tress, A. Abate and A. Hagfeldt, Cesium-containing triple cation perovskite solar cells: improved stability, reproducibility and high efficiency, Energ. Environ. Sci., 2016, 9, 1989-1997.

14. S.M. Huang, M.H. Hong, B.S. Luk'Yanchuk and T.C. Chong, Direct and subdiffraction-limit laser nanofabrication in silicon, Appl. Phys. Lett., 2003, 82, $4809-4811$

15. H.A. Atwater and A. Polman, Plasmonics for improved photovoltaic devices, Nat. Mater., 2010, 9, 205-213.

16. W. Shockley and H.J. Queisser, Detailed balance limit of efficiency of $p-n$ junction solar cells, J. Appl. Phys., 1961, 32, 510-519.

17. B. Ding, B.J. Lee, M. Yang, H.S. Jung and J.K. Lee, Surface - Plasmon Assisted Energy Conversion in Dye - Sensitized Solar Cells, Adv. Energy. Mater., 2011, 1, 415-421.

18. D. Zhang, M. Wang, A.G. Brolo, J. Shen, X. Li and S.M. Huang, Enhanced performance of dye-sensitized solar cells using gold nanoparticles modified fluorine tin oxide electrodes, J. Phys. D. Appl. Phys., 2012, 46, 32-44.

19. H.L. Ji, J.H. Park, J.S. Kim, Y.L. Dong and K. Cho, High efficiency polymer solar cells with wet deposited plasmonic gold nanodots, Org. Electron., 2009, 10, 416-420.

20. D.M. Schaadt, B. Feng and E.T. Yu, Enhanced semiconductor optical absorption via surface plasmon excitation in metal nanoparticles, Appl. Phys. Lett., 2005, 86, 
063106-063106-3.

21. Y. Chen, Z. Li, X. Chen, C. Liu, X. Ye, Z. Wang, Z. Sun and S. Huang, Improved performance of flexible amorphous silicon solar cells with silver nanowires, $J$. Appl. Phys., 2012, 112, 124320.

22. W. Zhang, M. Saliba, S.D. Stranks, Y. Sun, X. Shi, U. Wiesner and H.J. Snaith, Enhancement of perovskite-based solar cells employing core-shell metal nanoparticles, Nano. Lett., 2013, 13, 4505-4510.

23. M. Saliba, W. Zhang, V.M. Burlakov, S.D. Stranks, Y. Sun, J.M. Ball, M.B. Johnston, A. Goriely, U. Wiesner and H.J. Snaith, Plasmonic - Induced Photon Recycling in Metal Halide Perovskite Solar Cells, Adv. Funct. Mater. , 2015, 25, 5038-5046.

24. W.R. Erwin, H.F. Zarick, E.M. Talbert and R. Bardhan, Light trapping in mesoporous solar cells with plasmonic nanostructures, Energ. Environ. Sci., 2016, 9, 1577-1601.

25. Z. Yuan, Z. Wu, S. Bai, Z. Xia, W. Xu, T. Song, H. Wu, L. Xu, J. Si, Y. Jin and B. Sun, Hot - Electron Injection in a Sandwiched $\mathrm{TiO}_{\mathrm{x}}-\mathrm{Au}-\mathrm{TiO}_{\mathrm{x}}$ Structure for High - Performance Planar Perovskite Solar Cells, Adv. Energy. Mater., 2015, 5, 150038.

26. S.S. Mali, C.S. Shim, H. Kim, P.S. Patil and C.K. Hong, In situ processed gold nanoparticle-embedded $\mathrm{TiO}_{2}$ nanofibers enabling plasmonic perovskite solar cells to exceed 14\% conversion efficiency, Nanoscale, 2016, 8, 2664-2677.

27. Z. Jiang, X. Chen, X. Lin, X. Jia, J. Wang, L. Pan, S.M. Huang, F. Zhu and Z. Sun, Amazing stable open-circuit voltage in perovskite solar cells using AgAl alloy electrode, Sol. Energer. Mat. Sol. C, 2016, 146, 35-43.

28. K. Domanski, J.-P. Correa-Baena, N. Mine, M.K. Nazeeruddin, A. Abate, M. Saliba, W. Tress, A. Hagfeldt and M. Grätzel, Not All That Glitters is Gold: Metal Migration-Induced Degradation in Perovskite Solar Cells, ACS nano, 2016, 10, 6306-6314.

29. Y. Luo, X. Chen, C. Zhang, J. Li, J. Shi, Z. Sun, Z. Wang, and S. Huang, AgAl alloy electrode for efficient perovskite solar cells, RSC Adv., 2015, 5, 
$56037-56044$.

30. M. Gratzel, Photoelectrochemical cells, Nature, 1982, 414, 338.

31. V. Subramanian, E.E. Wolf and P.V. Kamat, Catalysis with $\mathrm{TiO}_{2} /$ gold nanocomposites. Effect of metal particle size on the Fermi level equilibration, $J$. Am. Chem. Soc., 2004, 126, 4943-4950

32. H.S. Jung, J.-K. Lee, M. Nastasi, S.-W. Lee, J.-Y. Kim, J.-S. Park, K.S. Hong and H. Shin, Preparation of nanoporous $\mathrm{MgO}$-coated $\mathrm{TiO}_{2}$ nanoparticles and their application to the electrode of dye-sensitized solar cells, Langmuir, 2005, 21, $10332-10335$

33. T. Taguchi, X.T. Zhang, I. Sutanto, K. Tokuhiro, T.N. Rao, H. Watanabe, T. Nakamori, M. Uragami and A. Fujishima, Improving the performance of solid-state dye-sensitized solar cell using $\mathrm{MgO}$-coated $\mathrm{TiO}_{2}$ nanoporous film, Chem. Commun., 2003, 19, 2480-2481.

34. J. Wang, M. Qin, H. Tao, W. Ke, Z. Chen, J. Wan, P. Qin, L. Xiong, H. Lei and H. $\mathrm{Yu}$, Performance enhancement of perovskite solar cells with $\mathrm{Mg}$-doped $\mathrm{TiO}_{2}$ compact film as the hole-blocking layer, Appl. Phys. Lett., 2015, 106, 591.

35. X. Guo, H. Dong, W. Li, N. Li and L. Wang, Multifunctional MgO Layer in Perovskite Solar Cells, ChemPhysChem, 2015, 16, 1727-1732.

36. Y. Yue, X. Yang, Y. Wu, N. T. Salim, A. Islam, T. Noda and L. Han, Selective Deposition of Insulating Metal Oxide in Perovskite Solar Cells with Enhanced Device Performance, ChemSusChem, 2015, 8, 2625-2629.

37. L. Gouda, R. Gottesman, A. Ginsburg, D.A. Keller, E. Haltzi, J. Hu, S. Tirosh, A.Y. Anderson, A. Zaban and P.P. Boix, Open circuit potential build-up in perovskite solar cells from dark conditions to 1 sun, J. Phys. Chem. Lett., 2015, 6, 46404645 .

38. H. J. Snaith and C. Ducati, $\mathrm{SnO}_{2}$-Based Dye-Sensitized Hybrid Solar Cells Exhibiting Near Unity Absorbed Photon-to-Electron Conversion Efficiency, Nano Lett., 2010, 10, 1259-1265.

39. H.W. Dong, D.Y. Kim, K.W. Choi, J.H. Seo, S.H. Im, J.H. Park, O.O. Park and A.J. Heeger, Rücktitelbild: Enhancement of Donor-Acceptor Polymer Bulk 
Heterojunction Solar Cell Power Conversion Efficiencies by Addition of $\mathrm{Au}$ Nanoparticles, Angew.Chem., 2011, 50, 5519-5523.

40. K. Catchpole and A. Polman, Plasmonic solar cells, Opt. Express., 2008, 16, 21793-21800.

41. J.-H. Im, C.-R. Lee, J.-W. Lee, S.-W. Park and N.-G. Park, 6.5\% efficient perovskite quantum-dot-sensitized solar cell, Nanoscale, 2011, 3, 4088-4093.

42. G. Zhu, T. Lin, X. Lü, W. Zhao, C. Yang, Z. Wang, H. Yin, Z. Liu, F. Huang and J. Lin, Black brookite titania with high solar absorption and excellent photocatalytic performance, J. Mater. Chem. A, 2013, 1, 9650-9653.

43. C. Huang, C. Liu, Y. Di, W. Li, F. Liu, L. Jiang, J. Li, X. Hao and H. Huang, Efficient Planar Perovskite Solar Cells with Reduced Hysteresis and Enhanced Open Circuit Voltage by Using $\mathrm{PW} 12-\mathrm{TiO}_{2}$ as Electron Transport Layer, ACS Appl. Mater. Inter., 2016, 8, 8520-8526.

44. H. Zhang, C. Liang, Y. Zhao, M. Sun, H. Liu, J. Liang, D. Li, F. Zhang and Z. He, Dynamic interface charge governing the current-voltage hysteresis in perovskite solar cells, Phys. Chem. Chem. Phys., 2015, 17, 9613-9618.

45. P.P. Boix, G. Larramona, A. Jacob, B. Delatouche, I. Mora-Seróand J. Bisquert, Hole transport and recombination in all-solid Sb2S3-sensitized $\mathrm{TiO}_{2}$ solar cells using CuSCN as hole transporter, J. Phys. Chem. C, 2011, 116, 1579-1587.

46. M.D. Brown, T. Suteewong, R.S.S. Kumar, V. D’Innocenzo, A. Petrozza, M.M. Lee, U. Wiesner and H.J. Snaith, Plasmonic Dye-Sensitized Solar Cells Using Core-Shell Metal-Insulator Nanoparticles, Nano. Lett., 2011, 11, 438-445.

47. A. Furube, L. Du, K. Hara, R. Katoh and M. Tachiya, Ultrafast plasmon-induced electron transfer from gold nanodots into $\mathrm{TiO}_{2}$ nanoparticles, J. Am. Chem. Soc., 2007, 129, 14852-14853.

48. A. Giugni, B. Torre, A. Toma, M. Francardi, M. Malerba, A. Alabastri, R. P. Zaccaria, M. I. Stockman and E. D. Fabrizio, Hot-electron nanoscopy using adiabatic compression of surface plasmons, Nat. Nanotechnol., 2013, 8, 845-852.

49. Z. Zhu, J. Ma, Z. Wang, C. Mu, Z. Fan, L. Du, Y. Bai, L. Fan, H. Yan and D. L. Phillips, Efficiency enhancement of perovskite solar cells through fast electron 
extraction: the role of graphene quantum dots, J. Am. Chem. Soc., 2014, 136, $3760-3763$.

50. J.M. Ball, S.D. Stranks, M.T. Hörantner, S. Hüttner, W. Zhang, E.J.W. Crossland, I. Ramirez, M. Riede, M.B. Johnston and R.H. Friend, Optical properties and limiting photocurrent of thin-film perovskite solar cells, Energ. Environ. Sci., $2015,8,602-609$.

51. Ghosh and Gorachand., Electronic handbook of optical constants of solids, Academic Press, 1999.

52. W. Fan, B. Yan, Z. Wang and L. Wu, Three-dimensional all-dielectric metamaterial solid immersion lens for subwavelength imaging at visible frequencies, Sci. Adv., 2016, 2, e1600901.

53. Q. Luo, Y. Chen, Z. Li, F. Zhu, X. Chen, Z. Sun, Y. Wei, H. Guo, Z. B. Wang and S. M. Huang, Large enhancements of $\mathrm{NaYF}_{4}: \mathrm{Yb} / \mathrm{Er} / \mathrm{Gd}$ nanorod upconversion emissions via coupling with localized surface plasmon of $\mathrm{Au}$ film, Nanotechnology, 2014, 25, 185401.

54. M. Bashevoy, V. Fedotov and N. Zheludev, Optical whirlpool on an absorbing metallic nanoparticle, Opt. Express, 2005, 13, 8372-8379.

55. S. K. Cushing, J. Li, F. Meng, T. R. Senty, S.Suri, M. Zhi, M. Li, A. D. Brristow and N. Q. Wu, Photocatalytic activity enhanced by plasmonic resonant energy transfer from metal to semiconductor, J. Am. Chem. Soc., 2012, 134, 1503315041

56. J. Li, S. K. Cushing, P. Zheng, F. Meng, D. Chu and N. Wu, Plasmon-induced photonic and energy transfer enhancement of solar water splitting by a hematite nanorod array. Nature Commun., 2013, 4, 2651.

57. L. M. Pazos-Outón, M. Szumilo, R. Lamboll, J. M. Richter, M. Crespo-Quesada, M. Abdi-Jalebi, H. J. Beeson, M. Vrućinić, M. Alsari and H. J. Snaith, Photon recycling in lead iodide perovskite solar cells, Science, 2016, 351, 1430-1433.

58. J. Even, L. Pedesseau and C. Katan, Analysis of Multivalley and Multibandgap Absorption and Enhancement of Free Carriers Related to Exciton Screening in Hybrid Perovskites, J. Phys. Chem. C, 2014, 118, 11566-11572. 
59. Q. Lin, A. Armin, R. C. R. Nagiri, P. L. Burn and P. Meredith, Electro-optics of perovskite solar cells, Nat. Photonics, 2015, 9, 106-112.

60. E. Yablonovitch, Lead halides join the top optoelectronic league, Science, 2016, 351, 1401-1401.

61. T. Leijtens, G. E. Eperon, S. Pathak, A. Abate, M. M. Lee and H. J. Snaith, Overcoming Ultraviolet Light Instability of Sensitized $\mathrm{TiO}_{2}$ with Meso-superstructured Organometal Tri-halide perovskite solar cells, Nat. Commun. 2014, 4, 2885.

62. W. Li, W. Zhang, S. Van Reenen, R. J. Sutton, J. Fan, A. A. Haghighirad, M. B. Johnston, L. Wang and H. J. Snaith, Enhanced UV-light Stability of Planar Heterojunction Perovskite Solar Cells with Caesium Bromide Interface Modification, Energy Environ. Sci., 2016, 9, 490-498.

63. S. Ito, S. Tanaka, K. Manabe and H. Nishino, Effects of Surface Blocking Layer of $\mathrm{Sb}_{2} \mathrm{~S}_{3}$ on Nanocrystalline $\mathrm{TiO}_{2}$ for $\mathrm{CH}_{3} \mathrm{NH}_{3} \mathrm{PbI}_{3}$ Perovskite Solar Cells, $J$. Phys. Chem. C, 2014, 118, 16995-17000. 


\section{Figure captions}

Fig. 1 (a) $J-V$ curves of devices based on $\mathrm{p}-\mathrm{TiO}_{2}$ without and with $\mathrm{Au} \mathrm{NP}$ and $\mathrm{MgO}$ coating. (b) FESEM image of the top surface morphology and (c) cross-sectional FESEM picture of the $\mathrm{p}-\mathrm{TiO}_{2}$ containing $\mathrm{Au}$ NPs. (d) Absorbance spectrum of $\mathrm{Au}$ suspension. (e) Energy diagram of materials for PSC devices with Au NP and MgO modification.

Fig. 2 (a) UV/Vis absorption and (b) PL spectra of perovskite absorbers based on p- $\mathrm{TiO}_{2}$ without and with $\mathrm{Au} \mathrm{NP}$ and $\mathrm{MgO}$ coating.

Fig. 3 Dark J-V curves of devices based on $\mathrm{p}-\mathrm{TiO}_{2}$ without and with $\mathrm{Au} \mathrm{NP}$ and $\mathrm{MgO}$ coating.

Fig. 4 (a) Nyquist plots of devices based on $\mathrm{p}-\mathrm{TiO}_{2}$ without and with $\mathrm{Au} \mathrm{NP}$ and $\mathrm{MgO}$ coating under dark condition at $0.9 \mathrm{~V}$ applied bias. (b) Simplified equivalent circuit to fit the impedance spectra.

Fig.5 (a) EQE spectra and (b) normalized EQE curves of devices based on p- $\mathrm{TiO}_{2}$ without and with $\mathrm{Au} \mathrm{NP}$ and $\mathrm{MgO}$ coating. (c) Calculated absorption depth of the absorber as a function of wavelength.

Fig.6 (a) Model of PSC device modified with both Au NPs and MgO. 2D field $|\mathrm{E}|$ enhancement distribution image in the $x z$ planes at (b) $\mathrm{y}=0 \mathrm{~nm}, \lambda=560 \mathrm{~nm}$, (c) $\mathrm{y}=0$ $\mathrm{nm}, \lambda=730 \mathrm{~nm}$. Power flow diagrams within the $x z$ planes at (d) $\mathrm{y}=0 \mathrm{~nm}, \lambda=560 \mathrm{~nm}$, (e) $\mathrm{y}=10 \mathrm{~nm}, \lambda=560 \mathrm{~nm}$, (f) $\mathrm{y}=0 \mathrm{~nm}, \lambda=730 \mathrm{~nm},(\mathrm{~g}) \mathrm{y}=10 \mathrm{~nm}, \lambda=730 \mathrm{~nm}$. Power flow diagrams within the $x y$ planes at $(\mathrm{h}) \mathrm{z}=0 \mathrm{~nm}, \lambda=730 \mathrm{~nm},(\mathrm{~g}) \mathrm{z}=18 \mathrm{~nm}, \lambda=730$ nm. 
Fig. 7 Power conversion efficiency variation of unsealed PSCs based on mesoporous $\mathrm{TiO}_{2}$ with and without $\mathrm{Au}$ NPs and $\mathrm{MgO}$ modification at $~ 55 \%$ humidity after various UV exposure durations $\left(90 \mathrm{mWcm}^{-2}\right.$ at $\left.365 \mathrm{~nm}\right)$ durations.

Table 1 Parameters of PSCs based on mesoporous $\mathrm{TiO}_{2}$ with and without $\mathrm{Au}$ NP and $\mathrm{MgO}$ modification.

Table 2 EIS results of PSCs based on mesoporous $\mathrm{TiO}_{2}$ with and without Au NPs and $\mathrm{MgO}$ modification. 